TERMINUS

t. 20 (2018), z. 1 (46), s. $85-120$

doi: $10.4467 / 20843844$ TE. 18.004 .8939

www.ejournals.eu/Terminus

Tadeusz Rubik 1 http://orcid.org/0000-0001-7647-2192

Uniwersytet Warszawski

rubiktadeusz@gmail.com

\title{
Disputationes de controversiis Christianae Fidei Roberta Bellarmina jako źródło komentarzy do Pisma Świętego przekładu Jakuba Wujka. Problematyka pośrednich zapożyczeń z Disputationes... na przykładzie Augustyna Biesiekierskiego ${ }^{1}$
}

Abstract

Robert Bellarmine's Disputationes de controversiis Christianae Fidei as a Source of Commentaries in Jakub Wujek's Translation of the Holy Writ: The Example of Augustyn Biesiekierski and Indirect Borrowings from Disputationes

1 Artykuł został złożony do druku przed ukazaniem się publikacji Pauliny Nicko-Stępień, Źródła dla komentarza tekstowego Nowego Testamentu w tłumaczeniu Jakuba Wujka z roku 1593. Studium Dz 2, 14-36, „Odrodzenie i Reformacja w Polsce”, 61 (2017), s. 235-257, podczas pracy nie miałem więc możliwości zapoznania się z wynikami badań autorki. Niniejszy artykuł ma nieco inny przedmiot badań (obejmuje również komentarze do Starego Testamentu, a także możliwą recepcję treści zawartych w adnotacjach biblijnych). Do wniosków badawczych Pauliny Nicko-Stępień odniosę się w innym miejscu. 
The first part of the paper is dedicated to the issues of adapting the Biblical commentaries on idolatry and 'entitled' depictions-originally featured in Disputationes de controversiis Christianae Fidei published by Robert Bellarmine-for the purpose of Jakub Wujek's endeavour to translate the Bible into Polish. A careful analysis has shown that at least four out of thirteen of the investigated commentaries are adaptations of Bellarmine's considerations in the form of translations or paraphrases. Building upon this discovery, the author proceeds to the second part of the paper, where he poses a question about the possibility of there being an indirect reception of Bellarmine's theological categories, which might have occurred in the discussed biblical commentaries. The problem is addressed by comparing Augustyn Biesiekierski's A Short Treatise on Adoration and Veneration of Sacred Images (the author made use of the Disputationes..., as proved by Piotr Krasny) and the content of respective commentaries.

Keywords: Jakub Wujek, Robert Bellarmine, Augustyn Biesiekierski, Bible, holy images, Biblical commentaries, intertextual relations

Monumentalne, trzytomowe kompendium Disputationes de controversiis Christianae Fidei Roberta Bellarmina (Ingolstadt 15811593) należało do podstawowych narzędzi katolickich polemistów w Rzeczypospolitej. Podczas dyskusji nad kształtem ratio studiorum to między innymi właśnie wileńscy jezuici przekonywali, aby Disputationes... uczynić podstawowym podręcznikiem teologii kontrowersyjnej². Zarówno Jakub Wujek, jak i Piotr Skarga już w latach 90. XVI wieku podczas opracowywania swoich tekstów nie tylko wykorzystywali sformułowane przez Bellarmina argumenty i kontrargumenty czy opracowane przez niego syntetyczne wykłady, lecz także tłumaczyli najcelniejsze fragmenty bez zasygnalizowania źródła ${ }^{3}$. To z kolei wzbudzało niechęć i oburzenie przedstawicieli różnych wy-

2 Zob. P. Urbański, Roberto Bellarmino (1542-1621) i wplyw jego myśli na rozwój kulturowych oraz religijnych idei w Rzeczypospolitej, w: Formowanie kultury katolickiej w dobie potrydenckiej. Powszechność i narodowość katolicyzmu polskiego, red. J. Dąbkowska-Kujko, Warszawa 2016, s. 199.

3 Zob. ibidem, s. 184, 202-203, 214, 221. 
znań protestanckich, o czym świadczy na przykład druk polemiczny Fausta Socyna Refutacyja ksiażek, które ks. Jakub Wujek jezuita wydat roku Pańskiego 1590 „O Bóstwie Syna Bożego i Ducha Św.”, w której zarazem się zbija to wszystko, co Robertus Bellarmino, także jezuita, tomo primo swoich „Dysputacyj” o tejże rzeczy napisat z 1593 roku. Wymieniony w tytule druk Wujka ,jest przeróbką Bellarminowego, bez jakiegokolwiek wskazania tego faktu w tekście"4.

Z Disputationes... korzystano także przy opracowaniu komentarzy („nauk i przestróg”, „wykładu miejsc trudniejszych”) do wydań Pisma Świętego w przekładzie Jakuba Wujka. Umieszczone na końcu poszczególnych rozdziałów ksiąg biblijnych wyjaśniają trudniejsze fragmenty tekstu (zwłaszcza stanowiące przedmiot sporu między katolikami a przedstawicielami wyznań protestanckich) i dostarczają filologicznych rozważań nad zasadnością takiego, a nie innego tłumaczenia. Jak informuje Przemowa do Czytelnika z wydania Nowego Testamentu z 1593 roku, komentarze te

częścią z samego Pisma Świętego, częścią też z wykładu starych onych ojców i doktorów kościelnych, których imiona mało nie wszędy są położone, częścią też i z nowych, a na imię z Bellarmina i z annotacji Nowego Testamentu angielskiego od katolików w Remsie we Francjej Roku Pańskiego 1582 wydanego, są zebrane ${ }^{5}$.

Wzmiankę o Robercie Bellarminie pomija Apparatus sacer, opracowany przez Marcina Łaszcza ${ }^{6}$ na podstawie - między innymi oryginalnej Przemowy Wujka wstęp do wydania całości Biblii z 1599 roku.

4 Ibidem, s. 202-203.

5 J. Wujek, Przemowa do Czytelnika, w: Nowy Testament, przeł. J. Wujek, Kraków: Andrzej Piotrkowczyk, 1593, s. 26. W cytatach z polskich i łacińskich druków szesnasto- i siedemnastowiecznych zmodernizowałem grafię i interpunkcję. Sigla biblijne uwspółcześniłem do zapisu stosowanego w Biblii Tysiąclecia. Wszystkie uwagi w nawiasach kwadratowych pochodzą ode mnie.

6 R. Pietkiewicz, Pismo Święte w języku polskim w latach 1518-1638. Sytuacja wyznaniowa w Polsce a rozwój edytorstwa biblijnego, Wrocław 2002, s. 184. 
Problematyka Disputationes de controversiis Christianae Fidei Roberta Bellarmina jako źródła komentarzy w wydaniach Pisma Świętego przekładu Jakuba Wujka była dotychczas sygnalizowana przez badaczy za przedmową z 1593 roku$^{7}$. Zgodnie z moją wiedzą nie została jednak opracowana - nie badano ani sposobu adaptacji rozważań Bellarmina, ani rozmiaru i zasięgu takich zapożyczeń (w sensie liczby komentarzy). Na temat różnych źródeł paratekstu Nowego Testamentu z 1593 roku prowadzi obecnie badania Paulina Nicko-Stępień ${ }^{8}$. W części pierwszej pokażę, w jaki sposób w komentarzach do Pisma Świętego adaptowano rozważania Roberta Bellarmina. Przedmiotem analiz będzie grupa wykładów związanych z problematyką prawomocności i nieprawomocności przedstawień oraz katolickiej sztuki religijnej.

Jak wykazał Piotr Krasny, rozważania Bellarmina o sztuce sakralnej dostarczyły narzędzi polemiczno-apologetycznych takim autorom, jak Augustyn Biesiekierski i Fabian Birkowski, a nawet Atanazy Kalnofojski, prawosławny mnich z Kijowa9. W części drugiej spróbuję wykazać, że Biesiekierski przy pracy nad Krótką nauką o czci i poszanowaniu obrazów świętych nie posiłkował się wyłącznie Dis-

7 Zob. D. Bieńkowska, Jak Jakub Wujek Pismo święte na język polski przekładał, „Bobolanum” 9, (1998) z. 1, s. 31; W. Smereka, Wstęp, w: Nowy Testament w przekładzie ks. dr Jakuba Wujka T.J. z roku 1593, Kraków 1966, s. XXXVII; J. Sobczykowa, Myśl o języku w komentarzu biblijnym ks. Jakuba Wujka, Katowice 2001, s. 19-20; D.A. Frick, Polish Sacred Philology in the Reformation and the Counter-Reformation, London 1989, s. 154. Frick zwrócił uwagę na pojawiające się w przedmowie do Nowego Testamentu z 1593 roku i Biblii z roku 1599 idee o bellarminowskiej proweniencji oraz włączone $\mathrm{w}$ tok wywodu tłumaczenia fragmentów tekstów tegoż autora, zob. ibidem, s. 150, 176, 193, 197, 213, 217.

8 Wspomina o tym Rajmund Pietkiewicz, Biblia Polonorum. Historia Biblii $w$ języku polskim, t. 1, Poznań 2016, s. 465-469; idem, Polskie antytrynitarskie przekłady Biblii $w$ dialogu Pierwszej Rzeczypospolitej ze wschodniq $i$ zachodniq Europa, w: Antytrynitaryzm w Pierwszej Rzeczypospolitej, red. M. Choptiany, P. Wilczek, Warszawa 2017, s. 273, przypis 35.

9 Zob. P. Krasny, Visibilia signa ad pietatem excitantes. Teoria sztuki sakralnej w pismach pisarzy kościelnych epoki nowożytnej, Kraków 2010, s. 184-199. 
putationes..., ale mógł korzystać również z komentarzy zawartych w wydaniu Biblii z 1599 roku.

Dla przedstawionych niżej rozważań nie jest decydujące, czy zawarte w tym wydaniu Pisma Świętego „wykłady miejsc trudniejszych" są oryginalnym tekstem Wujka (oryginalnym nie pod względem prezentowanych tez i interpretacji bądź sposobu opracowania treści, a w sensie językowej realizacji), warto jednak wspomnieć o sformułowanych wątpliwościach. Wujkowy przekład Pisma Świętego wraz z komentarzami po śmierci tłumacza przejrzała komisja pod przewodnictwem Stanisława Grodzickiego. Naniesione przez cenzorów zmiany objęły dużą część tekstu biblijnego, co rodzi słuszne zastrzeżenia do autentyczności komentarzy. Takie wątpliwości zgłaszał na przykład David A. Frick:

We must keep in mind that some of the renderings in the Bible of 1599 , as well as some of the opinions expressed in the prefaces and annotations, are not necessarily, and are often demonstrably not, those of Wujek himself ${ }^{10}$. [Musimy pamiętać, że zarówno niektóre rozstrzygnięcia translatorskie w $B i$ blii z 1599 roku, jak i część poglądów wyrażonych w przedmowach i adnotacjach, niekoniecznie pochodzą od samego Wujka, często zaś ewidentnie nie są jego autorstwa; przel. T.R.].

Joanna Sobczykowa ustaliła jednak:

tekst komentarza jest o wiele bardziej Wujkowy niż tekst biblijny, został bowiem zmieniony $\mathrm{w}$ minimalnym stopniu, $\mathrm{z}$ korzyścią dla poziomu naukowego zawartych w nim rozważań. [...]. Poza zrozumiałymi zmianami w partiach będących cytatami omawianych wyrażeń tekstowych, niejako nagłówkami cząstek komentarza, Jezuici zasadniczo pozostawili tu tekst Wujka, zachowując nawet w jego języku właściwości osobnicze autora [...]. Komentarz został bardzo starannie przepisany (powtórzony) - $\mathrm{z}$ dostosowaniem ortografii do sposobu przyjętego w druku Biblii. Dostępny do porównania materiał komentarzy, tj. Nowy Testament i Psałterz w wydaniu z 1599 r., zawiera przede wszystkim partie dodane: w 17 przypadkach chodzi o fragmenty komentarzy, a w 14 - o całe komentarze w formie osobnych

10 D.A. Frick, Polish Sacred Philology .., s. 134. 
akapitów pod rozdziałami tekstu biblijnego, co stanowi zaledwie niecałe $2 \%$ zmian nie wywołanych zmianą tekstu biblijnego ${ }^{11}$.

Nawet zmiany tekstu biblijnego nie w każdym przypadku przekładały się na zmianę cytatu odpowiedniego fragmentu - „nagłówka” w treści komentarza. Modyfikacji tego typu nie wprowadzono choćby w komentarzach do Ps 45,14 albo do Ps $48,7^{12}$; takie przeoczenie mogli popełnić zarówno cenzorzy, jak i zecer. Czasami pozostawiano nawet wykłady z kontrolowanego przez Wujka wydania Psałte$r z a$, które podważają zmiany wprowadzone przez komisję jezuitów, przedstawiając wybraną przez nich lekcję tekstu jako gorszy wariant. Ilustrują to na przykład komentarze do Ps 61,10 czy Ps $77,45^{13}$.

Jeśli nawet wykłady przeniesiono praktycznie bez zmian, nie daje to odpowiedzi na pytanie, czy to faktycznie Wujek napisał komentarze do kontrolowanych przez siebie wydań. Z pewnością to on był autorem uzasadnień konkretnych decyzji translatorskich. Jednakże rozpoznane przez Davida Fricka przeniesienie dużej części paratekstu Nowego Testamentu z 1593 roku z The New Testament of Iesus Christ Faithfully Translated into English z 1582 roku $^{14}$, również o charakterze dosłownego tłumaczenia, rodzi uzasadnione zastrzeżenia co do ich Wujkowego autorstwa ${ }^{15}$.

W związku z tymi wątpliwościami posługuję się w odniesieniu do autorstwa komentarzy formami bezosobowymi bądź stroną bierną.

11 J. Sobczykowa, Myśl o języku w komentarzu biblijnym..., s. 13-14.

12 Oznaczenia psalmów tu i dalej według numeracji łacińskiej.

13 Zob. T. Rubik, „Zgromadzenie marnych” - „zbór marności”. Ingerencja cenzorów w Psałterz przekładu Jakuba Wujka, w: Figura heretyka w nowożytnych sporach konfesyjnych, red. A. Bielak, W. Kordyzon, Warszawa 2017, s. 217, przypis 11.

${ }_{14}$ The New Testament of Iesus Christ Faithfully Translated into English, Reims: John Fogny, 1582.

15 Zob. D.A. Frick, Polish Sacred Philology..., s. 154, przypis 66; idem, Anglo-Polonica. The Rheims New Testament of 1582 and the Making of the Polish Catholic Bible, „The Polish Review”, 36 (1991), s. 47-67. 


\section{Disputationes... i „wykład miejsc trudniejszych”}

Grupę „wykładów miejsc trudniejszych” odnoszących się do problematyki prawomocności i nieprawomocności przedstawień oraz katolickiej sztuki religijnej można określić na podstawie Rejestru rzeczy przedniejszych i potrzebniejszych, które się $w$ Bibliej i $w$ annotacjach zamykaja z wydania Biblii z 1599 roku. Przedmiotem analizy będą więc komentarze odnoszące się do miejsc Pisma Świętego wskazywanych przez Rejestr... w hasłach „bałwan” i „obraz”"16. Ich treść porównuję $\mathrm{z}$ fragmentami traktatu Liber secundus de reliquiis et imaginibus sanctorum, zawartego w pierwszym tomie Disputationes... ${ }^{17}$. $\mathrm{W}$ analizie pomijam marginalne adnotacje.

Rejestr... wskazuje łącznie na trzynaście komentarzy związanych $\mathrm{z}$ prawomocnością bądź nieprawomocnością przedstawień oraz rodzajami czci, jaką można im oddawać. Są to komentarze do: Wj 20,4, Wj 20,5, Est 14,11, Mdr 14,12, Ba 6,3, Oz 1,2, Mt 9,21, Dz 5,15, Dz 17,29, 1 Kor 8,4, Flp 2,10, Hbr 11,33 oraz Ap 13,14. Cztery z ogółem trzynastu wykładów - Mt 9,21, Flp 2,10, Hbr 11,21, Ap 13,14 - są różnego rodzaju adaptacjami annotations z The New Testament of Iesus Christ Faithfully Translated into English ${ }^{18}$. Z pozostałych dziewięciu komentarzy cztery zidentyfikowałem jako zapożyczenia z Disputationes... Porównanie tekstu polskiego i łacińskiego znajduje się niżej, w tabelach 1-5.

16 Rejestr... nie wyczerpuje listy takich miejsc. Analiza innych fragmentów może okazać się z różnych względów interesująca (może np. odsłonić miejsca, których autor Rejestru... nie chciał wskazać czytelnikowi). Problematykę obrazów porusza na przykład niewymieniony w Rejestrze... komentarz do Ps 113,16 (wyjaśnienie, że grzech bałwochwalstwa polega nie na samym sporządzaniu „rycin”, a dopiero na oddawaniu im nieuprawnionej czci).

17 R. Bellarmin, Disputationes de controversiis Christianae Fidei, vol. 1, Ingolstadt: David Sartorius, 1586, szp. 2089-2157.

18 Komentarz do Mt 9,21 jest dosłownym tłumaczeniem $\mathrm{z}$ The New Testament..., s. 24; Flp 2,10 z kolei skróconą adaptacją ze s. 531; Hbr 10,11 tłumaczeniem początku i skrótem dalszej części komentarza ze s. 633; Ap 13,14 tłumaczeniem ze s. 723. 
W kolumnie „Typ zapożyczenia” wymieniam obok literalnych tłumaczeń i parafraz również similia. Na ich identyfikację jako zależnych od tekstu Disputationes... pozwala wzgląd na kontekst parafraz i fragmentów literalnego przekładu. Postrzegane $w$ takich ramach mają wyraźne przełożenie na jednolitość wywodu i jego zgodność $\mathrm{z}$ argumentacją Bellarmina. Bez tego kontekstu similia te jawiłyby się $\mathrm{w}$ większości po prostu jako popularne tropy katolickiej apologetyki przedstawień ${ }^{19}$.

Tabela 1. Zestawienie komentarza do Wj 20,4 z fragmentami Disputationes...

\begin{tabular}{|c|c|c|c|}
\hline $\mathrm{Nr}$ & Komentarz do Wj 20, 4 & $\begin{array}{c}\text { Typ } \\
\text { zapożyczenia }\end{array}$ & Fragmenty Disputationes... \\
\hline 1 & 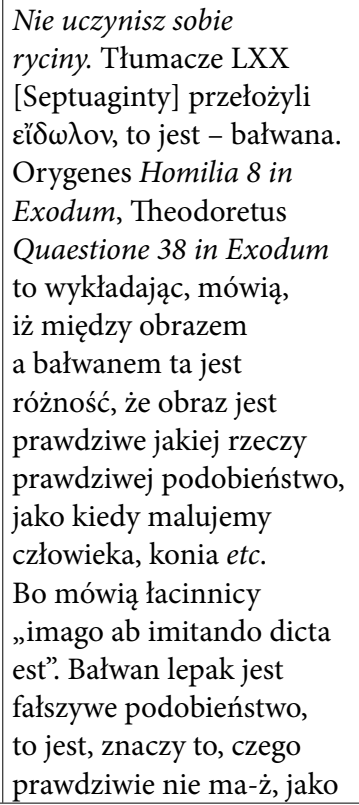 & $\begin{array}{l}\text { literalne } \\
\text { tłumaczenie }\end{array}$ & $\begin{array}{l}\text { [szp. 2089-2090] [...] } \\
\text { Origenes Homilia octava } \\
\text { in Exodum et Theodoretus } \\
\text { Quaestione } 38 \text { in Exodum } \\
\text { exponentes illud Exodi } \\
20 \text { [Wj 20]: „Non facies } \\
\text { tibi sculptile (quod LXX } \\
\text { verterunt e` } \delta \omega \lambda \text { ov) et } \\
\text { omnem similitudinem” etc., } \\
\text { dicunt inter imaginem et } \\
\text { idolum hoc interesse, quod } \\
\text { imago est vera rei similitudo, } \\
\text { ut cum pingimus hominem, } \\
\text { equum etc. Imago enim ab } \\
\text { imitando dicta est. Idolum } \\
\text { autem est falsa similitudo, } \\
\text { id est, repraesentat id, quod } \\
\text { revera non est, ut cum } \\
\text { gentiles }\end{array}$ \\
\hline
\end{tabular}

19 Zob. na przykład J. Wujek, O obraziech, w: Pisarze polskiego Odrodzenia o sztuce, oprac. W. Tomkiewicz, Wrocław 1955, s. 233-242; J. Wujek, Iudicium abo Rozsądek niektórych katolików o konfesjej sędomierskiej roku 1570 wydanej [...], Kraków: Mikołaj Szarfenberg, 1570, k. 44r.-53r. 


\begin{tabular}{|c|c|c|c|}
\hline $\mathbf{N r}$ & Komentarz do Wj 20, 4 & $\begin{array}{c}\text { Typ } \\
\text { zapożyczenia }\end{array}$ & Fragmenty Disputationes... \\
\hline 1 & $\begin{array}{l}\text { słupy Wenerze abo } \\
\text { Minerwie etc. One znaki } \\
\text { bałwanem były, iż znaczyły } \\
\text { bogi abo boginie takie, } \\
\text { jakowych nie ma-ż ani być } \\
\text { mogą, a tak ani prawdziwie } \\
\text { znaczyły, ale były fałszywe } \\
\text { znaki. Stąd rozumiemy, } \\
\text { iż obrazy Chrystusowe } \\
\text { i świętych nie są bałwany, } \\
\text { i przetoć nigdziej Pismo } \\
\text { prawdziwego obrazu nie } \\
\text { zowie bałwanem, ale tylko } \\
\text { ryciny pogańskie }{ }^{\star} \text { tak } \\
\text { zowie, iż fałszywe bogi } \\
\text { znaczyły. [...] }\end{array}$ & & $\begin{array}{l}\text { proponebant statuas Veneris } \\
\text { aut Minervae, illa signa idola } \\
\text { erant, quia repraesentabant } \\
\text { deos generis foeminini, } \\
\text { quales dii nec sunt, nec esse } \\
\text { possunt. Atque ita nec vere } \\
\text { repraesentabant, sed erant } \\
\text { falsae imagines. [...] Ex } \\
\text { quo intelligimus imagines } \\
\text { Christi et sanctorum non } \\
\text { esse idola [...] quia Scriptura } \\
\text { nusquam tribuit nomen idoli } \\
\text { ulli verae imagini, sed solum } \\
\text { simulacris gentilium, quae } \\
\text { falsos deos referebant. }\end{array}$ \\
\hline 2 & $\begin{array}{l}\text { I tak prorok święty } \\
\text { Abakuk } 2 \text { [Ha 2] zowie } \\
\text { takie ryciny obrazem } \\
\text { fałszywym i Paweł Święty } \\
1 \text { Kor } 8 \text { mówi: „Wiemy, iż } \\
\text { bałwan nic nie jest”. }\end{array}$ & simile & $\begin{array}{l}\text { [szp. 2090] Denique } \\
\text { Habacuch secundo [Ha } \\
\text { 2] ait Scriptura [...] ubi } \\
\text { clarissime definitur idolum } \\
\text { imago falsa. [...] Beatus } \\
\text { Paulus 1 Corinth. } 8 \text { [1 Kor 8] } \\
\text { ait: „Scimus, quia nihil est } \\
\text { idolum in mundo” [...] }\end{array}$ \\
\hline
\end{tabular}

* Zastanawiające jest oddanie simulacra gentilium jako „rycin pogańskich”. To nietypowe tłumaczenie pozwala wytłumaczyć grupa ingerencji cenzorów przekładu, którzy skorygowali Wujkowe dzieło po jego śmierci, w tekst Psałterza (oryginalna wersja znana jest $\mathrm{z}$ kontrolowanego przez tłumacza wydania $\mathrm{z} 1594$ roku) oraz komentarz odnoszący się do Ps 113,16. Cenzorzy konsekwentnie zmieniali „bałwany” jako tłumaczenie sculptile właśnie na „rycinę”, a kontrowersyjne zdanie „grzech bałwochwalstwa [...] jest nie w czynieniu bałwana abo obrazu" we wspomnianym komentarzu przekształcili na "grzech bałwochwalstwa [...] jest nie w czynieniu ryciny abo obrazu". Komentarz ten zachowuje również (prawdopodobną) pierwotną redakcję tekstu pierwszego przykazania - tłumacz proponował nie "nie sporządzisz sobie ryciny" (tak w wydaniu z 1599 roku, zarówno w Wj 20,4, jak i w komentarzu do Ps 113,16), a "nie sporządzisz sobie obrazu” (tak w komentarzu z 1594 roku). Jeśli w tekście Wj 20,4 mowa o zakazie sporządzania „ryciny”, to komentarz naturalnie powinien odnosić się właśnie do „rycin”. Zmiana ta jest więc najprawdopodobniej jedną z nielicznych ingerencji cenzorów w tekst komentarzy, dlatego jawi się jako istotna. 


\begin{tabular}{|c|c|c|c|}
\hline $\mathrm{Nr}$ & Komentarz do Wj 20, 4 & $\begin{array}{c}\text { Typ } \\
\text { zapożyczenia }\end{array}$ & Fragmenty Disputationes... \\
\hline 3 & $\begin{array}{l}\text { Nie zakazuje tedy } \\
\text { tu obrazów, jako to } \\
\text { nowowiernicy źle } \\
\text { wykładają, ale zakazuje } \\
\text { rycia i wszelakiego } \\
\text { podobieństwa, któreby } \\
\text { miały boga fałszywego } \\
\text { znaczyć, co pospolicie } \\
\text { pismo zowie bałwanem. } \\
\text { Levit } 18 \text { i } 19 \text { [Kpł } 18 \text { i 19]. }\end{array}$ & simile & $\begin{array}{l}\text { [szp. 2096] Et sine dubio } \\
\text { non prohibetur in decalogo } \\
\text { omnis imago, sed solum illa, } \\
\text { quae dici potest idolum, id } \\
\text { est, imago, quae habetur pro } \\
\text { deo, vel quae repaesentant } \\
\text { tanquam deum eam rem, } \\
\text { quae non est deus. }\end{array}$ \\
\hline 4 & $\begin{array}{l}\text { Bo gdy tu mówi: „Nie } \\
\text { będziesz miał bogów } \\
\text { cudzych, zakazuje } \\
\text { wnętrznej wiary i chwały”, } \\
\text { a gdy przydaje: „Nie } \\
\text { uczynisz sobie ryciny”, } \\
\text { zakazuje i zwierzchniej czci } \\
\text { i znaku tymże bałwanom } \\
\text { czynić. Augustinus } \\
\text { Quaestio } 7 \text { [sic!] in } \\
\text { Exodum. }\end{array}$ & $\begin{array}{l}\text { literalne } \\
\text { tłumaczenie }\end{array}$ & $\begin{array}{l}\text { Cum enim dicitur: „Non } \\
\text { habebis Deos alienos”, } \\
\text { prohibetur actus interior } \\
\text { idololatrie. Cum autem } \\
\text { additur: „Non facies tibi } \\
\text { sculptile” etc. Prohibetur } \\
\text { actus exterior. Vide } \\
\text { Augustinum quaestione } 71 \text { in } \\
\text { Exodum. }\end{array}$ \\
\hline 5 & $\begin{array}{l}\text { I możem tegoż z Pisma } \\
\text { dowieść, ponieważ }\end{array}$ & - & $\begin{array}{l}\text { [brak bezpośredniego } \\
\text { zapożyczenia] }\end{array}$ \\
\hline 6 & $\begin{array}{l}\text { [...] czytamy, iż obrazy } \\
\text { były czynione z rozkazania } \\
\text { Bożego, jako niżej Exod. } 25 \\
\text { [Wj 25] rozkazał uczynić } \\
\text { obrazy cherubinów nad } \\
\text { skrzynią i Num. } 21 \text { [Lb 21] } \\
\text { węża miedzianego i } 3 \text { Król. } \\
6 \text { i } 7 \text { [1 Krl } 6 \text { i 7] cherubiny, } \\
\text { lwy, woły. }\end{array}$ & $\begin{array}{l}\text { literalne } \\
\text { tłumaczenie }\end{array}$ & $\begin{array}{l}\text { [szp. 2096-2097] [...] } \\
\text { legimus imagines factas Dei } \\
\text { iussu, siquidem Exodi } 25 \\
\text { Deus fieri iussit imagines } \\
\text { Cherubin super arcam. } \\
\text { Num. } 21 \text { [Lb 21] serpentem } \\
\text { aeneum, } 3 \text { Reg. } 6 \text { et } 7 \text { [ } 1 \text { Krl } 6 \\
\text { i 7] cherubim, boves, leones } \\
\text { et alia. }\end{array}$ \\
\hline 7 & $\begin{array}{l}\text { I rzemiosła malarskiego } \\
\text { i snycarskiego sam Bóg } \\
\text { nauczył Exod. } 31 \text { i } 34 \\
\text { [Wj } 31 \text { i } 34, \text { sic!]. }\end{array}$ & simile & $\begin{array}{l}\text { [szp. 2097] [...] ars pingendi } \\
\text { et sculpendi bona est et } \\
\text { a Deo, ut patet Exodi } 31 \text { et } 35 \\
\text { [Wj } 31 \text { i 35]. [...] }\end{array}$ \\
\hline
\end{tabular}




\begin{tabular}{|c|c|c|c|}
\hline $\mathrm{Nr}$ & Komentarz do Wj 20, 4 & $\begin{array}{c}\text { Typ } \\
\text { zapożyczenia }\end{array}$ & Fragmenty Disputationes... \\
\hline 8 & $\begin{array}{l}\text { Na ostatek Żydowie za } \\
\text { czasu Pana Chrystusa } \\
\text { mieli obrazy cesarskie na } \\
\text { pieniądzach, Math. } 22 \\
\text { [Mt 22]. }\end{array}$ & parafraza & $\begin{array}{l}\text { [szp. 2097-2098] Denique } \\
\text { Iudaei tempore Christi } \\
\text { habebant imaginem Caesaris } \\
\text { in nummis, ut patet Matth. } \\
22 \text { [Mt 22]. }\end{array}$ \\
\hline 9 & $\begin{array}{l}\text { Toć tedy Bóg nie zakazał } \\
\text { obrazów, ale tylko } \\
\text { bałwanów, jako to niżej } \\
\text { verso } 23 \text { w tymże rozdziale } \\
\text { wykłada, mówiąc: „Nie } \\
\text { będziesz czynić bogów } \\
\text { srebrnych ani bogów } \\
\text { złotych”. A tak grzeszy } \\
\text { ten przeciw przykazaniu } \\
\text { Bożemu, kto rycie abo } \\
\text { podobieństwa jakie czyni, }\end{array}$ & - & $\begin{array}{l}\text { [brak bezpośredniego } \\
\text { zapożyczenia] }\end{array}$ \\
\hline 9 & $\begin{array}{l}\text { aby je za bogi chwalił, abo } \\
\text { fałszywych bogów znakami } \\
\text { były, ale ten nie grzeszy, kto } \\
\text { obrazy prawdziwe dla czego } \\
\text { przystojnego czyni. Jako } \\
\text { w Kościele Bożym mamy } \\
\text { obrazy, aby nam były jako } \\
\text { księgi Ewanjelijej i żywotów } \\
\text { świętych, abyśmy nie } \\
\text { przepominali tych, których } \\
\text { miłujemy. I żebychmy } \\
\text { takimi znakami cnotliwe } \\
\text { i świątobliwe sprawy ludzi } \\
\text { świętych czcili, i dla inszych } \\
\text { względów są obrazy nasze, } \\
\text { ale nigdy dlatego, abyśmy } \\
\text { je mieli za bogi chwalić - } \\
\text { potwarz to jest heretycka. }\end{array}$ & - & $\begin{array}{l}\text { [brak bezpośredniego } \\
\text { zapożyczenia] }\end{array}$ \\
\hline
\end{tabular}




\begin{tabular}{|l|l|l|l|}
\hline $\mathbf{N r}$ & \multicolumn{1}{|c|}{ Komentarz do Wj 20, 4 } & \multicolumn{1}{|c|}{$\begin{array}{c}\text { Typ } \\
\text { zapożyczenia }\end{array}$} & Fragmenty Disputationes... \\
\hline $\mathbf{1 0}$ & $\begin{array}{l}\text { Skąd każdy obaczyć może, } \\
\text { że to jest jedno przykazanie. } \\
\text { Nie będziesz miał cudzych } \\
\text { bogów przede Mną. I nie } \\
\text { uczynisz sobie ryciny } \\
\text { i żadnego podobieństwa. } \\
\text { Bo tu zakazuje tylko } \\
\text { jednej rzeczy, to jest } \\
\text { chwalić cudzych bogów } \\
\text { i podobieństwa ich, inaczej } \\
\text { byłoby nie dziesięcioro, }\end{array}$ & $\begin{array}{l}\text { [szp. 2096] Probatur haec } \\
\text { sententia primum, quia si } \\
\text { prohibetur omnis imago, } \\
\text { sequeretur praecepta } \\
\text { decalogi non esse tantum } \\
\text { decem, sed undecim, vel } \\
\text { duodecim contra Scipturam, } \\
\text { quae dicit esse decem, Exod. }\end{array}$ \\
\hline $\mathbf{1 0}$ & & ale jedenaście przykazania 34 [Wj 31 i 34]. \\
& & sożego przeciw jawnemu \\
pismu Exod 31, 34 [Wj 31 & & \\
i 34], Deut 4,9 i 10 [Pwt 4, & & \\
& $9 ; 10]$. & \\
\hline
\end{tabular}

Komentarz ma dwudzielną strukturę. W części pierwszej (tabela 1, 1-2) przeniesiono rozważania - przez przetłumaczenie obszernego ich fragmentu - z rozdziału De nomine imaginis et idoli (szp. 20892091), to jest rozróżnienie na imago i idolum (równe simulacrum) ze względu na relację przedstawień $\mathrm{z}$ pierwowzorem. Część druga (tabela 1,4-10) to syntetyczny wykład katolickiego uzasadnienia przedstawień i omówienie ich funkcji. Części te łączy fragment trzeci tabeli 1. O ile tekst wykładu wydaje się aplikować kategorię „fałszywości" przedstawienia (rozumianą jako brak realnie istniejącego pierwowzoru) do rozważań nad prawomocnością przedstawień, o tyle u Bellarmina myśl ta jest wyraźnie odizolowana od rozważań nad wspomnianą opozycją. Posługuje się też definicją "bałwana” inną od tej $\mathrm{z}$ fragmentu tabeli 1, 1, a więc definicją nieuwzględniają- 
cą relacji do pierwowzoru. Skupia się za to na kwestii postrzegania przedstawienia jako bóstwa ${ }^{20}$.

Co więcej, znajdujący się w drugiej części komentarza wykład teologiczny mógłby spokojnie obyć się bez rozważań adaptowanych $\mathrm{z}$ rozdziału De nomine imaginis et idoli. Wszystkie chyba prezentowane w nim argumenty pojawiały się w tradycji już przed działalnością Bellarmina ${ }^{21}$. Zakaz dotyczy przedstawień pogańskich, a nie chrześcijańskich (tabela 1, 1-3 i 9). Grzech bałwochwalstwa polega na oddawaniu jakiejkolwiek czci pogańskim wizerunkom (tabela 1,4), chrześcijańskim zaś jedynie czci należnej samemu Bogu, od czego wyraźnie odcina się katolicka nauka (tabela 1,9 ). Obrazy są z różnych względów przydatne i pożyteczne (tabela 1,9 ), poza tym samo Pismo dostarcza przykładów wizerunków sporządzanych przez wyznawców Boga na Jego wyraźne polecenie (tabela 1, 5-7). Jednocześnie - to odparcie zarzutu na przykład ewangelików reformowanych, niewymienionych w komentarzu - jeśli w Wj 20,3-5 wyróżniałoby się dwa przykazania (nakaz czci jednego Boga i zakaz sporządzania wizerunków), a nie jedno, prowadziłoby to do sprzeczności z Biblią, która mówi o dziesięciu przykazaniach (tabela 1,10$)^{22}$. Zarzuty formułowane przez polemistów protestanckich różnych wyznań wobec

20 W Disputationes... o ściśle uporządkowanej strukturze użycie pojęcia wraz $\mathrm{z}$ wyjaśnieniem id est [...] wskazuje na wywołanie go w znaczeniu innym od wcześniej zdefiniowanego.

21 Zob. na przykład literaturę w przypisie 19. Wprowadzenie opozycji imago-idolum miało na celu przede wszystkim wykazanie, że zrównywanie katolickich obrazów z bałwanami przez protestanckich polemistów jest bezzasadne, zob. P. Krasny, Visibilia signa ad pietatem excitantes..., s. 63-65. Był to skuteczny zabieg (zob. ibidem, s. 133) i to właśnie wydaje się znaczącym wkładem Bellarmina w dyskusję o obrazach. Wcześniej pozornie dialogujący polemiści raczej wyrażali autorytarne twierdzenia, odwołujące się do różnych założeń, zob. np. Grzegorz z Żarnowca, Kazanie o obraziech i bałwaniech, w: Pisarze polskiego Odrodzenia..., s. 218-232; J. Wujek, O obraziech, s. 233-242, Konfesja sandomierska, oprac. K. Długosz-Kurczabowa, Warszawa 1995, s. 44-48, J. Wujek, Iudicium..., k. 44r.-53r.

22 Oczywiście ewangelicy reformowani nie uznawali jedenastu przykazań. Za jedno, dziesiąte, uznawali katolickie przykazanie dziewiąte i dziesiąte, zob. na przykład R. Bellarmin, Disputationes de controversiis..., szp. 2090. 
katolickich przedstawień nie są dokładnie omawiane (w odróżnieniu od tekstu Disputationes...), można je jednak wyczytać ze struktury wykładu pozytywnego.

Ta część komentarza (tj. tabela 1,3-10) składa się z szeregu fragmentów literalnego przekładu, parafraz bądź similiów z Licere imagines et facere et habere (szp. 2095-2099), chociaż niepodążających za tokiem wywodu Bellarmina. Wykład odnosi się do najistotniejszych elementów wymienionego rozdziału z pominięciem bardziej subtelnych rozważań teologicznych (np. omówienia tez Ambrosiusa Catharinusa, czyli Lancelotta Politiego, albo Tommasa Gaetana, właśc. de Vio, szp. 2098-2099), powołuje się także na znacznie mniejszą liczbę źródeł teologicznych oraz wersetów biblijnych. Przy okazji warto zwrócić uwagę na dwa błędy w odnośnikach transponowanych z Disputationes... Przywołane rozważania Augustyna nad komentowanym wersetem Księgi Wyjścia znajdują się w istocie w 71 kwestii drugiej księgi Quaestionum in Heptateuchum libri septem, a nie w 7, jak wskazuje komentarz (tabela 1, 4). Bóg nauczył Bezelela i Oliaba rzemiosła w Wj 35, a nie 34 (tabela 1, 7). Prawdopodobnie nie da się rozstrzygnąć, czy te pomyłki (i na pewno wiele podobnych) popełnił autor komentarza, świecki kopista, który przepisywał rękopis prze$\mathrm{kładu}^{23}$, czy zecer. Niewykluczone, że autor po prostu przepisywał sigla i odnośniki do dzieł teologicznych z Disputationes...

Omawiane w De nomine imaginis et idoli oraz w komentarzu do Wj 20,4 rozróżnienie na imago i idolum bądź jego ślady znajdują się również w komentarzach do Est 14,11 oraz 1 Kor 8,4 (zob. tabele 1 i 2 ).

23 Zob. K. Drzymała, Wpływ księdza Stanisława Grodzickiego T.J. na tłumaczenie Biblii ks. Jakuba Wujka T.J., „Polonia Sacra” 4, (1951), nr 1, s. 77. 
Tabela 2. Zestawienie komentarza do Est 14,11 z fragmentami Disputationes...

\begin{tabular}{|c|c|c|c|}
\hline $\mathrm{Nr}$ & $\begin{array}{l}\text { Komentarz do } \\
\text { Est } 14,11\end{array}$ & $\begin{array}{c}\text { Typ } \\
\text { zapożyczenia }\end{array}$ & $\begin{array}{c}\text { Fragmenty Disputationes..., } \\
\text { szp. } 2090\end{array}$ \\
\hline 1 & $\begin{array}{l}\text { Nie dawaj sceptrum } \\
\text { twego tym, którzy nie są. } \\
\text { To jest bałwanom, }\end{array}$ & $\begin{array}{l}\text { literalne } \\
\text { tłumaczenie }\end{array}$ & [zob. wiersz nr 5 w tej tabeli] \\
\hline 2 & $\begin{array}{l}\text { bo bałwan nic nie jest, } \\
\text { jako też mówi Apostoł } \\
1 \text { Kor } 8 \text {, a chocia } \\
\text { materyja bałwana jest } \\
\text { cokolwiek, wszakże sam } \\
\text { bałwan nic nie jest, bo } \\
\text { to znaczy, czego nie } \\
\text { ma-ż, znaczy bogi } \\
\text { fałszywe, jakowych nie } \\
\text { ma-ż, a tak prawdziwie } \\
\text { nic nie znaczy i nic } \\
\text { nie jest. }\end{array}$ & $\begin{array}{l}\text { literalne } \\
\text { tłumaczenie } \\
\text { (zmiana } \\
\text { kolejności } \\
\text { składniowej) }\end{array}$ & $\begin{array}{l}\text { [TERTIO,] quia B. Paulus } \\
1 \text { Corinth. } 8 \text { [1 Kor } 8 \text { ] ait: } \\
\text { „Scimus, quia nihil est idolum } \\
\text { in mundo”, ubi idolum nihil } \\
\text { esse dicitur, quia licet sit } \\
\text { aliquid secundum materiam, } \\
\text { tamen nihil est formaliter, } \\
\text { cum id repraesentat, quod } \\
\text { nihil est, et proinde nec vere } \\
\text { repraesentat, et proinde nec sit. } \\
\text { [Cui loco... ] }\end{array}$ \\
\hline 3 & $\begin{array}{l}\text { A tym ci są różne } \\
\text { obrazy od bałwanów, iż } \\
\text { obrazy właśnie znaczą } \\
\text { i wyrażają to, co jest } \\
\text { albo było, a przetoć są } \\
\text { własnym wyrażeniem } \\
\text { i znakiem rzeczy } \\
\text { pewnych i tych, które } \\
\text { właśnie są. A bałwany } \\
\text { znaczą rzeczy niepewne } \\
\text { i których nie ma-ż. }\end{array}$ & parafraza & $\begin{array}{l}\text { [por. definicja „bałwana” } \\
\text { w tabeli 1, wiersz 1], } \\
\text { Disputationes... szp. 2089- } \\
\text { 2090] }\end{array}$ \\
\hline 4 & $\begin{array}{l}\text { [brak odpowiadającego } \\
\text { fragmentu] }\end{array}$ & - & $\begin{array}{l}\text { [...nec sit.] Cui loco alium } \\
\text { similem adducit Hieronymus } \\
\text { in capite } 7 \text { Oseae [Oz 7], ad } \\
\text { probandum idolum nihil esse; } \\
\text { nam Hester secundum LXX } \\
\text { dicitur: }\end{array}$ \\
\hline 5 & [zob. wiersz nr 1] & $\begin{array}{l}\text { literalne } \\
\text { tłumaczenie }\end{array}$ & $\begin{array}{l}\text { „Ne tradas sceptrum tuum his, } \\
\text { qui non sunt”, id est, idolis. }\end{array}$ \\
\hline
\end{tabular}


Komentarz (tabela 2) adaptuje rozważania ze szpalty 2090 jako wyjaśnienie znaczenia wersetu Est 14,11; w pełni odpowiada nazwie „wykładu miejsca trudniejszego”. W Disputationes... „ontologiczna” egzegeza fragmentu 1 Kor 8,4 doprecyzowuje pojęcia „idola” („[...] licet [idolum] sit aliquid secundum materiam, tamen nihil est [idolum] formaliter [...]") i głębiej zakorzenia opozycję zdefiniowaną w szpaltach 2089-2090 w gruncie Pisma („Hanc esse veram differentiam illarum vocum [imago, idolum] secundum Ecclesiasticos, probatur PRIMO [...]. SECUNDO [...]. TERTIO, quia Beatus Paulus [...]"). Powołanie się na werset z Księgi Estery w dalszym ciągu wywodu uprawomocnia przedstawioną interpretację 1 Kor 8,4 przez wskazanie biblijnego simile oraz poparcie takiego odczytania autorytetem świętego Hieronima.

Autor zmodyfikował kolejność części fragmentu De nomine imaginis et idoli, a jedną pominął, tak aby komentarz współgrał $\mathrm{z}$ wersetem, który wyjaśnia (zob. tabela 2, 1, 4 i 5). Brak odniesienia do Hieronima można postrzegać jako uproszczenie Bellarminowych rozważań. Bardzo skrócona parafraza tez z komentarza do Wj 20,4 oraz szpalt 2089-2090 Disputationes... osadza omawiany „wykład miejsca trudniejszego" w prezentowanych tam rozważaniach (tabela 2,3). Para wykładów (tj. do Wj 20,4 i Est 14,11) w Rejestrze... znajduje się pod hasłem „Bałwany różne od obrazów”; nie ma jednak żadnego marginalium - zarówno przy tekście głównym, jak i komentarzu - które by je łączyło. 
Tabela 3. Zestawienie komentarza do 1 Kor 8,4 z fragmentami Disputationes...

\begin{tabular}{|l|l|l|l|}
\hline Nr & Komentarz do 1 Kor 8, 4 & \multicolumn{1}{|c|}{$\begin{array}{c}\text { Typ } \\
\text { zapożyczenia }\end{array}$} & $\begin{array}{c}\text { Fragmenty } \\
\text { Disputationes..., } \\
\text { szp. 2090 }\end{array}$ \\
\hline $\mathbf{1}$ & $\begin{array}{l}\text { Bałwan nic nie jest. Nie } \\
\text { z strony materyjej, która } \\
\text { cożkolwiek jest, ale ze } \\
\text { strony formy, iż to znaczy, } \\
\text { co nic nie jest, }\end{array}$ & $\begin{array}{l}\text { literalne } \\
\text { tłumaczenie }\end{array}$ & $\begin{array}{l}\text { „Scimus, quia nihil est } \\
\text { idolum in mundo", ubi } \\
\text { idolum nihil esse dicitur, } \\
\text { quia licet sit aliquid } \\
\text { secundum materiam, } \\
\text { tamen nihil est formaliter, } \\
\text { cum id repraesentat, quod } \\
\text { nihil est, }\end{array}$ \\
\hline $\mathbf{2}$ & $\begin{array}{l}\text { abo czego nie masz na } \\
\text { świecie. }\end{array}$ & parafraza & $\begin{array}{l}\text { et proinde nec vere } \\
\text { repraesentat, et proinde } \\
\text { nec sit. }\end{array}$ \\
\hline
\end{tabular}

Komentarz (zob. tabela 3), podobnie jak ten do Est 14,11, tłumaczy i parafrazuje krótki fragment szpalty 2090 Disputationes... w formie wyjaśnienia, jak mówi marginalium, ,jako bałwan nic nie jest”. I w tym przypadku brakuje marginaliów bądź siglów biblijnych, które odnosiłyby wykład do innego miejsca Pisma Świętego.

Znacznie obszerniejszy jest wykład do Dz 17,29, trawestujący rozważania z Non esse prohibitas imagines Dei. W tym rozdziale Robert Bellarmin odpierał zarzuty przede wszystkim Jana Kalwina przeciw prawomocności przedstawień, omawiał również na przykład błędy Bartholomé de Carranza y Miranda, dominikanina więzionego pod zarzutem herezji przez prawie siedemnaście lat. Tekst wykładu podzieliłem na dwie tabele. W tabeli 4 znajduje się początek komentarza, a w tabeli 5 zakończenie, w którym przepisano fragment kazania O obraziech z Wujkowej Postylli. 
Tabela 4. Zestawienie pierwszej części komentarza do Dz 17,29 z fragmentami Disputationes...

\begin{tabular}{|c|c|c|c|}
\hline $\mathrm{Nr}$ & Komentarz do Dz 17,29 & $\begin{array}{c}\text { Typ } \\
\text { zapożyczenia }\end{array}$ & $\begin{array}{c}\text { Fragmenty } \\
\text { Disputationes... }\end{array}$ \\
\hline 1 & $\begin{array}{l}\text { Bóstwo miało być podobne. } \\
\text { Spierają się kalwinistowie, } \\
\text { iż się nie godzi } \\
\text { niewidzianego Boga zgoła } \\
\text { nijako malować, }\end{array}$ & parafraza & $\begin{array}{l}\text { [szp. 2099] [Iohannes } \\
\text { Calvinus] dicit [...], } \\
\text { nefas esse Deo invisibili } \\
\text { et incorporeo imaginem } \\
\text { visibilem et corpoream } \\
\text { collocare. }\end{array}$ \\
\hline 2 & $\begin{array}{l}\text { przeto iż Bóstwo } \\
\text { niewidziane nie może } \\
\text { być żadnym widzianym } \\
\text { obrazem wyrażone, }\end{array}$ & parafraza & $\begin{array}{l}\text { [szp. } 2100][\ldots] \text { quia } \\
\text { non videtur posse fieri } \\
\text { imaginem corpoream rei } \\
\text { incorporeae }[\ldots]\end{array}$ \\
\hline 3 & $\begin{array}{l}\text { i nas katoliki potwarzają, } \\
\text { jakobyśmy obrazami Trójce } \\
\text { Świętej Bóstwo wyrazić } \\
\text { chcieli. }\end{array}$ & - & $\begin{array}{l}\text { [brak bezpośredniego } \\
\text { zapożyczenia] }\end{array}$ \\
\hline 4 & $\begin{array}{l}\text { Lecz jako aniołowie, } \\
\text { chocia także są niecieleśni } \\
\text { i niewidziani i żadnym } \\
\text { obrazem wyrażeni być nie } \\
\text { mogą, a wżdy przedsię } \\
\text { w Starym Zakonie byli } \\
\text { malowani i rzezani, } \\
\text { i w kościele stawiani, }\end{array}$ & parafraza & $\begin{array}{l}\text { [szp. 2101] [...] Angeli } \\
\text { sunt incorporei, et tamen } \\
\text { depicti et sculpti sunt } \\
\text { in Testamento Veteri, } \\
\text { Exod. } 25 \text { [Wj 25], } 3 \text { Reg. } 6 \\
\text { [1 Krl 6] quare, Deus etiam } \\
\text { licet incorporeus pingi } \\
\text { potest. }\end{array}$ \\
\hline 5 & $\begin{array}{l}\text { tak też Bóg Ojciec i Duch } \\
\text { Święty przeczby nie miał } \\
\text { być malowany, zwłaszcza } \\
\text { w tych figurach, w których } \\
\text { się sam pokazować raczył: }\end{array}$ & parafraza & $\begin{array}{l}\text { [zob. wiersz nr } 9 \mathrm{w} \text { tej } \\
\text { tabeli] }\end{array}$ \\
\hline 6 & $\begin{array}{l}\text { jako Adamowi w raju } \\
\text { w osobie człowieczej, } \\
\text { jako Jakobowi, wsparłszy } \\
\text { się na wierzchu drabiny, } \\
\text { Izajaszowi i Micheaszowi } \\
\text { siedzący na stolicy. Daniel } \\
\text { go maluje, }\end{array}$ & simile & $\begin{array}{l}\text { [szp. 2101] [...] Deus visus } \\
\text { est corporea specie, nam } \\
\text { Adae apparuit „tanquam } \\
\text { homo deambulans in } \\
\text { paradiso ad auram post } \\
\text { meridiem”. Genes. } 3 \\
\text { [Rdz 3] Iacob vidit Deum } \\
\text { „innixum summitati } \\
\text { scalae”, et }\end{array}$ \\
\hline
\end{tabular}




\begin{tabular}{|c|c|c|c|}
\hline $\mathrm{Nr}$ & Komentarz do Dz 17,29 & $\begin{array}{c}\text { Typ } \\
\text { zapożyczenia }\end{array}$ & $\begin{array}{c}\text { Fragmenty } \\
\text { Disputationes... }\end{array}$ \\
\hline 6 & & & $\begin{array}{l}\text { proinde forma corporea, } \\
\text { Gen. } 28 \text { [Rdz 28]. Moyses } \\
\text { vidit „posteriora Dei”, id est } \\
\text { terga et humeros, Exodi } 33 \\
\text { [Wj 33]. Isaias capite } 6 \\
\text { [Iz 6] et Micheas } 3 \text { [Mi 3]. } \\
\text { Reg [1 Krl]. Ult viderunt } \\
\text { „Dominum sedentem in } \\
\text { solio” ad formam hominis } \\
\text { regis. Et Amos capite } 9 \\
\text { [Am 9] vidit Dominum } \\
\text { „stantem super altare”. } \\
\text { Denique Daniel capite } 7 \\
\text { [Dn 7]. [...]. }\end{array}$ \\
\hline 7 & $\begin{array}{l}\text { jako go widział na stolicy } \\
\text { siedzącego i opisuje głowę } \\
\text { jego i włosy jego siwe, } \\
\text { i szaty białe*. }\end{array}$ & $\begin{array}{l}\text { tłumaczenie } \\
\text { literalne }\end{array}$ & $\begin{array}{l}\text { [szp. 2101] vidit eum } \\
\text { „sedentem in throno”, et } \\
\text { describit caput, et capillos } \\
\text { eius canos, et vestimenta } \\
\text { eius alba. }\end{array}$ \\
\hline 8 & $\begin{array}{l}\text { Duch Święty ukazał } \\
\text { się w osobie gołębice } \\
\text { i w ognistych językach, } \\
\text { czemużby w tychże } \\
\text { figurach nie miał być } \\
\text { malowany? }\end{array}$ & simile & $\begin{array}{l}\text { [szp. 2101] Spiritus sanctus } \\
\text { apparauit „in forma } \\
\text { columbae”, Matth. } 3 \text { [Mt 3]. } \\
\text { [...] Quid ergo prohibet sic } \\
\text { pingi? }\end{array}$ \\
\hline 9 & $\begin{array}{l}\text { [zob. wiersz nr } 5 \mathrm{w} \text { tej } \\
\text { tabeli] }\end{array}$ & parafraza & $\begin{array}{l}\text { [szp. 2101] [...] } \\
\text { contendimus posse Deum } \\
\text { pingi in ea forma, in qua } \\
\text { seipsum demonstravit. }\end{array}$ \\
\hline
\end{tabular}

* Od słów „i żadnym obrazem wyrażeni być nie mogą” do „opisuje głowę jego i włosy jego siwe i szaty białe” znajdują się marginalia z siglami: „Wj 25,29, $1 \mathrm{Krl} 6,23$ [do tego miejsca przykłady przedstawień aniołów]. Figury, w których się Bóg okazować raczył: Rdz 3,8, Iz 6,1, 1 Krl 22,10, Dn 7,9 [przykłady epifanii Boskich]". Wszystkie te przykłady występują w szpalcie 2101 Disputationes..., jednakże tylko $\mathrm{z}$ numerami rozdziałów. 
Tabela 5. Druga część komentarza do Dz 17,29

\begin{tabular}{|c|c|c|c|}
\hline $\mathrm{Nr}$ & $\begin{array}{c}\text { Komentarz do Dz } \\
17,29\end{array}$ & $\begin{array}{c}\text { Tekst O obraziech, } \\
\text { s. } 241\end{array}$ & $\begin{array}{c}\text { Similia } \\
\text { z Disputationes... }\end{array}$ \\
\hline 10 & $\begin{array}{l}\text { A zwłaszcza } \\
\text { iż w katolickim Kościele } \\
\text { obrazy Trojce Świętej } \\
\text { nie przeto malują, } \\
\text { żeby im podobieństwo } \\
\text { Bóstwa i niedościgłej } \\
\text { natury jego wyrazić } \\
\text { chcieli abo żeby } \\
\text { rozumieli być Boga tym } \\
\text { obrazom podobnego. }\end{array}$ & $\begin{array}{l}\text { Wszakże jednak } \\
\text { nie dla tego obrazy } \\
\text { Trójce Świętej katolicy } \\
\text { malują, żeby onymi } \\
\text { podobieństwo bóstwa } \\
\text { i niedościgłej natury } \\
\text { jego wyrazić chcieli } \\
\text { albo żeby rozumieli } \\
\text { być Boga tym obrazom } \\
\text { podobnego, }\end{array}$ & $\begin{array}{l}\text { [szp. 2103] Uno } \\
\text { modo [pingendi] } \\
\text { ad exprimendem } \\
\text { perfectam } \\
\text { similitudinem formae } \\
\text { et naturae rei ipsius. Et } \\
\text { hoc modo res corporea } \\
\text { solum pinguntur, quae } \\
\text { lineamentis et coloribus } \\
\text { praeditae sunt. Et si } \\
\text { quis hac ratione Deum } \\
\text { pingere tenerater, } \\
\text { is verum idolum } \\
\text { constitueret] } \\
\end{array}$ \\
\hline 11 & $\begin{array}{l}\text { Bo to jest kacerstwo } \\
\text { antropomorfitów } \\
\text { mniemać, żeby Bóg } \\
\text { miał także ręce, oczy, } \\
\text { nogi jako człowiek. }\end{array}$ & $\begin{array}{l}\text { bo to jest kacerstwo } \\
\text { antropomorfitów } \\
\text { mniemać, żeby Bóg } \\
\text { miał także oczy, ręce } \\
\text { i nogi jako człowiek, }\end{array}$ & $\begin{array}{l}\text { [por. szp. 2101-2102, } \\
\text { fragment niecytowany] }\end{array}$ \\
\hline 12 & $\begin{array}{l}\text { Ale przeto te obrazy } \\
\text { stawiają, aby ludzie } \\
\text { temi znaki pobudzeni } \\
\text { na Pana Boga żywego } \\
\text { i niewidzianego } \\
\text { wspominali i różność } \\
\text { trzech osób Trójce } \\
\text { Przenaświętszej przez te } \\
\text { widome figury niejako } \\
\text { zrozumieli. }\end{array}$ & \begin{tabular}{|l|} 
ale przeto te obrazy \\
stawiają, aby ludzie \\
tymi znaki pobudzeni \\
na Pana Boga żywego \\
wspominali i różność \\
trzech osób Trójce \\
Przenaświętszej przez te \\
widome figury niejako \\
zrozumieli.
\end{tabular} & $\begin{array}{l}\text { [szp. 2105] [...] imago } \\
\text { Dei et Trinitatis, } \\
\text { ut a nobis pingitur, } \\
\text { doctor est veritatis, } \\
\text { quia neque habetur } \\
\text { pro deo a nobis, neque } \\
\text { sit ad referendam } \\
\text { Dei effigiem, sed } \\
\text { ad perducendum } \\
\text { hominem in aliquam } \\
\text { Dei notitiam per } \\
\text { analogicas similitudines } \\
\text { [zob. szp. } 2103 \text {, } \\
\text { fragment niecytowany] }\end{array}$ \\
\hline
\end{tabular}




\begin{tabular}{|c|c|c|c|}
\hline $\mathrm{Nr}$ & $\begin{array}{c}\text { Komentarz do Dz } \\
17,29\end{array}$ & $\begin{array}{c}\text { Tekst O obraziech, } \\
\text { s. } 241\end{array}$ & $\begin{array}{c}\text { Similia } \\
\text { z Disputationes... }\end{array}$ \\
\hline 13 & $\begin{array}{l}\text { Przetoż te obrazy Trójce } \\
\text { Świętej nie sąć kształty } \\
\text { i figury samego Boga } \\
\text { żywego, którego żaden } \\
\text { rozum ogarnąć, nie } \\
\text { rzkąc, malarz wyrazić } \\
\text { nie może, ale są figury } \\
\text { widomych i cielesnych } \\
\text { rzeczy, w których się } \\
\text { Bóg ludziom zjawić } \\
\text { i pokazać raczył. }\end{array}$ & $\begin{array}{l}\text { Przetoż te obrazy Trojce } \\
\text { Świętej nie sąć kształty } \\
\text { i figury samego Boga } \\
\text { żywego, którego żaden } \\
\text { rozum ogarnąć, nie } \\
\text { rzkąc, malarz wyrazić } \\
\text { nie może, ale są figury } \\
\text { tych rzeczy, w których } \\
\text { się Pan Bóg ludziom } \\
\text { zjawić i pokazać raczył: } \\
\text { jako Bóg Ociec } \\
\text { w osobie męża siwego } \\
\text { Danielowi, a Duch } \\
\text { Święty w osobie } \\
\text { gołębice przy krzcie } \\
\text { Pana Chrystusowym. }\end{array}$ & $\begin{array}{l}\text { [zob. szp. } 2103, \\
\text { fragment niecytowany] }\end{array}$ \\
\hline
\end{tabular}

* W szpalcie 2103 Bellarmin na potrzeby odparcia argumentu wyróżnia trzy typy wizerunków. Zarzut Kalwina miałby opierać się na potraktowaniu przedstawień niecielesnego Boga jako obrazów primi generis (wyjaśnione w tabeli 4, 10), katolicy jednak nie w taki sposób malują Boga. Alterus modus polega na „wystawieniu przed oczy jakiejś historii [biblijnej]”, w takim typie wizerunku nie chce się wyrazić natury Boga i w taki sposób wolno Go przedstawiać. Do trzeciego typu wizerun$\mathrm{ku}$, „analogicznego albo mistycznego”, zaliczają się na przykład alegorie cnót oraz człowiek jako stworzony na obraz Boga. Fragment z wiersza 12 tabeli 5 przypomina część definicji obrazów trzeciego rodzaju.

Pierwsza część komentarza do Dz 17,29 (zob. tabela 4) adaptuje rozważania z Disputationes..., odchodząc od oryginału dalej niż wykłady omówione wyżej. Składa się prawie wyłącznie z parafraz i similiów, prawdopodobnie dlatego, że odpiera zarzut Kalwina (tabela 4, 1-3) przedstawiony w sposób ogólny, bez analizowania jego poszczególnych przesłanek i elementów (tabela 4,2 ). W obszernym rozdziale Non esse prohibitas imagines Dei Bellarmin z kolei szczegółowo rekonstruował poszczególne przesłanki tezy o absolutnej niemożliwości przedstawienia Boga, na przykład oparte na fragmentach Pisma albo twierdzeniu, że maluje się rzeczy nieobecne, 
a Bóg obecny jest wszędzie (szp. 2099-2100). Wiersze 1 i 2 tabeli 4 parafrazują początek i koniec Bellarminowego streszczenia zastrzeżeń Kalwina omówionych w tych szpaltach.

We fragmentach komentarza $\mathrm{z}$ wierszy $4-8$ tabeli 4 transponowano z Disputationes... wybrane odpowiedzi na poszczególne tezy Kalwina w formie argumentów przeciw zarzutowi z wierszy 1-3 tejże tabeli. Anioły, również niecielesne, prawomocnie przedstawiano w Starym Testamencie (tabela 4, 4). Boga przedstawia się w postaciach, w jakich się objawiał (a więc był „widziany”, tabela 4,5 ). Niektóre jego epifanie wymieniona są w wierszach 6-8 tabeli 4. Dalsza część komentarza, przepisana z Wujkowego kazania $O$ obraziech (zob. tabela 5), kontynuuje argumentację przeciw zarzutowi Kalwina. Katolickie obrazy nie próbują wyrażać natury Boga (tabela 4, 10), a wzmacniają pobożność i - operując Boskimi znakami z Biblii dają o nim pewne pojęcie (tabela 4,12). Fragment $\mathrm{z}$ wiersza 11 tabeli 4 można interpretować jako skierowane do wiernych pouczenie $^{24}$. Część wykładu $\mathrm{z}$ wiersza 13 tabeli 4 podsumowuje rozważania przedstawione we wcześniejszych partiach $\mathrm{w}$ formie pozytywnych informacji teologicznych o charakterze obrazów.

Jak pokazuje zestawienie $\mathrm{w}$ tabeli 5 , rozważania przepisane $\mathrm{z}$ kazania $O$ obraziech są zgodne z tokiem wywodu Non esse prohibitas imagines Dei. Autor dostosował tę cząstkę do wcześniejszej partii tekstu. Zastąpił „wszakże jednak”, w oryginalnym kontekście sygnalizujące przeciwstawność i zastrzeżenie do poprzedniego twierdzenia, zwrotem „a zwłaszcza iż”, czyniąc z fragmentu warunek możliwości

24 Również Fabian Birkowski w kazaniu z 1629 roku tuż po streszczeniu rozważań Bellarmina z Non esse prohibitas imagines Dei (zob. P. Krasny, Visibilia signa ad pietatem excitantes..., s. 189-195) dodawał, przypominając wiernym: „I przeto prostszych ludzi uczyć trzeba o tych obraziech, bo oni prędko padną na to, iż Bóg ma ciało i postać człowieczą [...]”, F. Birkowski, O świętych obrazach, jako maja być szanowane, w: Głos krwie b. Józefata Kunczewica archiepiskopa połockiego także b. Jana Sarkandra męczennika morawskiego i obrazu bransbergskiego przytem o śś. obrazach, jako mają być szanowane kazania czworo, Kraków 1859, s. 72-73. 
przedstawienia ${ }^{25}$. Pominął przykłady Boskich epifanii, ponieważ omówił je już dokładniej za Bellarminem (zob. tabela 4, 4-8, tabela 5,13$)^{26}$. Co więcej, w przepisanym fragmencie zawierają się implicite dwa z trzech wyróżnionych przez włoskiego jezuitę typów obrazów ${ }^{27}$. Autor mógł zdecydować się przepisać fragment z Wujkowej Postylli, widząc, że doskonale zgadza się $\mathrm{z}$ argumentacją Bellarmina, którą się wspierał.

Podobnie jak w komentarzu do Wj 20,4 (zob. tabela 1) uproszczono rozważania z Disputationes...: znacznie zmniejszono liczbę powołań na fragmenty biblijne oraz $\mathrm{w}$ ogóle zrezygnowano $\mathrm{z}$ odwołań do tekstów teologicznych. Autor nie zdecydował się jednak na to w przypadku wspomnianego wyżej wykładu. Z prezentowanych w Disputationes... argumentów zaczerpnął te o największej sile przekonywania, zwłaszcza osób nieobeznanych $\mathrm{z}$ subtelnościami teologicznymi (np. „,zemuż nie wolno przedstawiać Boga w takich postaciach, w jakich sam się pokazał?").

Omówienie komentarzy do Wj 20,4 Est 14,11, 1 Kor 8,4 oraz Dz 17,29 pokazuje, że zapożyczenia z Disputationes... w obrębie wykładów mogą mieć rozmaity charakter. Są to komentarze zawierają-

25 Można przedstawiać Osoby Trójcy Świętej w postaciach, w jakich się ukazywały, aby ,jako tam [w Piśmie Świętym] uszyma, tak tu oczyma były pojmowane. Wszakże jednak nie dlatego obrazy [...] malują, żeby onymi podobieństwo Bóstwa i niedościgłej natury jego wyrazić chcieli [...]", J. Wujek, O obraziech, s. 241. O ile w pierwotnym kontekście cytowany w tabeli 5 fragment kazania ma charakter zastrzeżenia do zezwolenia na sporządzanie przedstawień zgodnych z Boskimi epifaniami („owszem, można, wszakże jednak nie chodzi o to, aby wyrazić naturę"), o tyle w kontekście wykładu jego znaczenie się zmienia - „owszem, można, a zwłaszcza iż nie chodzi o to, aby wyrazić naturę".

26 Podobny argument pojawia się również w Iudicium: „Może być Pan Bóg malowany i wyrażony tak, jako się nam w Piśmie sam pod figurami pokazać raczył: jako gdy go z Daniela malują jako starca jakiego na stolcu siedzącego, a przed nim księgi otworzone [...]. Także Ducha Świętego malują w gołębicy albo w językach, w których się pokazać raczył, a Syna Bożego w swoim człowieczeństwie, ponieważ $\mathrm{z}$ niewidzianego stał się nam widzianym", J. Wujek, Iudicium..., k. 44v.

27 Zob. przypis 26. 
ce wyłącznie krótkie wskazówki egzegetyczne (Est 14,11, 1 Kor 8,4), mniej lub bardziej łączące się $\mathrm{z}$ wykładami treści teologicznych $\mathrm{w}$ innych miejscach. Takie zapożyczenia są zapewne najliczniejsze w całym aparacie, którym opatrzono Wujkowe tłumaczenie Biblii, a zarazem także najtrudniejsze do pewnego zidentyfikowania ze względu na ich niewielką długość. Do innego rodzaju wykładu należy ten do Wj 20,4, w sposób syntetyczny przyswajający w wykładzie treści teologicznych obszerne fragmenty rozważań z Disputationes... Jeszcze inny typ komentarza egzemplifikuje adnotacja odnosząca się do Dz 17,29, która na podstawie (między innymi) opus vitae Bellarmina rozwiązuje pojedynczy protestancki argument, oparty na konkretnych fragmentach Pisma Świętego. Kilka komentarzy (Wj 20,4, Est 14,11, 1 Kor 8,4) może łącznie - systematycznie, choć krótko przekazywać specyficznie Bellarminowskie kategorie, w tym przypadku opozycję „bałwana” i „obrazu” definiowanych ze względu na ich relację do pierwowzoru. Powyższe uogólnienia, oparte na niewielkim materiale, mają charakter wyłącznie roboczy i wymagają weryfikacji z większą liczbą komentarzy opartych na Disputationes...

\section{II. „Wykład miejsc trudniejszych” a Krótka nauka o czci i poszanowaniu obrazów świętych}

Czy opisane adaptacje myśli Bellarmina w komentarzach do wydań Pisma Świętego przekładu Jakuba Wujka mogły zaowocować pośrednią recepcją tez włoskiego jezuity w tekstach polskich autorów? Spróbuję odpowiedzieć na to pytanie, porównując treść komentarzy biblijnych z fragmentami Krótkiej nauki o czci i poszanowaniu obrazów świętych Augustyna Biesiekierskiego z 1624 roku.

Jest to jeden $z$ trzech tekstów wskazanych przez Piotra Krasnego jako przykłady polskiej recepcji myśli Bellarmina o sztuce. Oprócz niego badacz omówił kazanie $O$ świętych obraziech jako mają być szanowane Fabiana Birkowskiego z 1629 roku oraz Teratourgema 
lubo Cuda które byly tak w samym świętocudotwornym monastyru Pieczarskim Kijowskim... Atanazego Kalnofojskiego z 1638 roku $^{28}$. Ze wszystkich trzech autorów tylko prawosławny Kalonofojski powołał się imiennie na Bellarmina. Birkowski $z$ kolei już na samym początku kazania adaptuje rozważania jezuity z rozdziałów De nomine imaginis et idoli oraz Non esse prohibitas imagines Dei, trudne łacińskie terminy oddając precyzyjnie w języku polskim ${ }^{29}$.

Krótka nauka... dzieli się na dwie części. Pierwsza z nich, do k. 13v., zawiera wykład katolickiej nauki o obrazach, część druga od k. 14r. - to apologia krakowskiego kościoła Bożego Ciała na Kazimierzu oraz znajdującego się w nim obrazu Matki Boskiej, który Biesiekierski przypisywał Łukaszowi Ewangeliście. Analiza porównawcza obejmuje rozdział drugi, Pan Bóg nie zakazał obrazów, z pierwszej części Krótkiej nauki... oraz komentarze biblijne odnoszące się do fragmentów wymienionych w Rejestrze... pod hasłami „obraz” i „bałwan”. Celem analizy jest nie systematyczne opracowanie zależności tekstu Biesiekierskiego od wykładów, a wykazanie, że autor posługiwał się komentarzami do Pisma Świętego jako źródłem równorzędnym z Disputationes... Ustalenia Piotra Krasnego pokazują, że w omawianym druku znajdują się echa koncepcji z dzieła Bellarmina, których brak w wykładach, Biesiekierski musiał więc posiłkować się również odpowiednimi rozdziałami Disputationes... Poza tym odebrał edukację w wileńskim kolegium, a zarówno przed opuszczeniem zakonu jezuitów, jak i już po wstąpieniu do kanoników laterańskich św. Augustyna w 1621 roku, wykładał teologię, można więc z pewnością stwierdzić, że dobrze znał Bellarminowy podręcznik ${ }^{30}$.

28 Zob. przypis 9.

29 Zob. F. Birkowski, O świętych obrazach..., s. 71-73, R. Bellarmin, Disputationes de controversiis..., szp. 2089-2090 i 2099-2105. Birkowski posługuje się na przykład nieobecnymi u Wujka terminami „reprezentacji” czy „metaforyczności obrazu".

30 Zob. Encyklopedia katolicka, t. 2, red. F. Gryglewicz, R. Łukaszyk, Z. Sułowski, Lublin 1985, szp. 583. 
Piotr Krasny wskazał na kilka zapożyczeń z Disputationes... w Krótkiej nauce... Pierwszym z nich są tropy wskazujące na obecność opozycji imago-idolum (równe simulacrum) oraz przekonanie

w ślad za jezuickim teologiem, że w drugim przykazaniu Bóg nie zabrania obrazów, ponieważ „mówiąc, nie będziesz sobie czynił bałwana, dodaje, abyś go chwalił.

Z tych tedy i inszych miejsc podobnych widzimy, iż Pan Bóg podobieństwa albo bałwanów, które były miasto Boga, zakazał". Oddanie bellarminowskiego simulacrum jako podobieństwa nie było może zbyt szczęśliwe $[\ldots]^{31}$.

Po drugie, za włoskim kardynałem, Biesiekierski przytacza argument na rzecz prawomocności świętych obrazów - są one miłe Bogu, ponieważ działa przez nie cuda. Również wyjaśnienie tego, że wydarzają się one nierównomiernie przy wszystkich obrazach, pochodzi z pism Bellarmina ${ }^{32}$.

Z Disputationes... wywodzi się także obfity katalog pożytków, które wierni mogą czerpać z użytkowania świętych obrazów, oraz próba wyjaśnienia, jaka cześć należna jest wizerunkom, a jaka wyłącznie Bogu. Zdaniem Krasnego Biesiekierski znał „bellarminowskie rozróżnienie na adorationem należne tylko Bogu i venerationem, przysługujące również jego wizerunkom" i choć wyrażenie go było - rzekomo - poza możliwościami Biesiekierskiego, to jednak jego „nieudolne” tłumaczenie wykorzystuje „apologetyczną siłę tej dychotomii" ${ }^{33}$.

31 P. Krasny, Visibilia signa ad pietatem excitantes..., s. 186.

32 Zob. ibidem, s. 187-188.

33 Ibidem, s. 188-189. Autor wskazywał również na dążenie Biesiekierskiego do prostoty wywodu, pisząc: „Biesiekierski zdecydował się [...] na zastąpienie wykwintnych spekulacji i wywodów konkretnymi regułami formułowanymi w dobitny sposób. Taka forma wykładu była dostosowana do możliwości polskich odbiorców, nieskłonnych raczej do percepcji głębokich filozoficznych i teologicznych rozważań, ale podatnych na retoryczną wyrazistość oracji”, ibidem, s. 189. Mimo tych zastrzeżeń twierdził jednak, że „precyzyjne opisanie charakteru czci, która jest należna obrazom, przekraczało możliwości skromnej teologicznej polszczyzny Biesiekierskiego. Kanonik ów znał jednak bellarminowskie rozróżnie- 
Omówione wyżej ustalenia można przyjąć bez większych zastrzeżeń. Argumentacja Piotra Krasnego przekonuje, że są to faktycznie zapożyczenia z Disputationes..., a nie odwołania do miejsc wspólnych katolickiej apologetyki przedstawień. Wyjątek stanowią ślady opozycji imago-idolum, które pochodzą raczej z komentarza do Wj 20,4 (zob. niżej).

Warto przytoczyć w całości rozdział drugi Krótkiej nauki...: Pan Bóg nie zakazał obrazów $w^{34}$ :

[A] Szturmując na obrazy, heretycy z Żydami pospołu przywodzą Pismo Święte, zadając katolikom bałwochwalstwo, w czym niewstydliwie nas potwarzają. [B] Wiedzieć tedy potrzeba, iż Pan Bóg zakazał bałwanów, które są znakami fałszywemi rzeczy fałszywych, a nie zakazał obrazów, które są znakami prawdziwemi rzeczy prawdziwych. Tak się rozumie Pisma Świętego miejsce, gdy mówi [Wj 20,2, sic!]: „Nie uczynisz sobie rycia ani żadnego podobieństwa. Nie będziesz się im kłaniał ani służył”. Także i na innym miejscu: „Nie będziesz miał Bogów cudzych przed oczyma moimi” [Pwt 5,8]. I w trzecich księgach Mojżeszowych, mówiąc: „Nie będziesz sobie czynił bałwana” [Kpł 26,2, sic!], dodaje: „abyś go chwalił”35. Z tych tedy i inszych miejsc podobnych widzimy, iż Pan Bóg podobieństwa abo bałwanów, które

nie na adorationem należne tylko Bogu i venerationem, przysługujące również jego wizerunkom. Pojęcia te przekładał dość nieudolnie jako „cześć oddawaną «wyższym» lub «niższym» obyczajem [...]”, ibidem, s. 188. Wydaje się jednak, że „nieudolność" tego tłumaczenia należy zrzucić raczej na karb intencji Biesiekierskiego niż na ubóstwo jego teologicznej polszczyzny bądź teologicznej polszczyzny w ogóle.

$34 \mathrm{~W}$ nawiasach kwadratowych znajdują się obecne w druku marginalia z siglami biblijnymi. Litery w nawiasach kwadratowych oznaczają podział tekstu na potrzeby niniejszej analizy.

$35 \mathrm{~W}$ istocie jest to werset 1 rozdziału 26, którego Wujkowe tłumaczenie brzmi „Nie będziecie sobie czynić bałwana ani ryciny [...], żebyście się mu kłaniali”, Biblia, to jest Księgi Starego i Nowego Przymierza, przeł. J. Wujek, Kraków: Drukarnia Łazarzowa, 1599. Być może autor cytuje z pamięci albo świadomie parafrazuje. Możliwe jednak, że posługuje się jakimś źródłem łacińskim, np. Disputationes..., gdzie w szpalcie 2097 Bellarmin pisze: „Levit. 26 [Kpł 26] «Non facietis sculptile et idolum, ut adoretis»". Wulgata syksto-klementyńska podaje takie brzmienie: „Non facietis vobis idolum et sculptile [...], ut adoretis eum”, Biblia Sacra vulgatae editionis, Roma: Typographia Apostolica Vaticana, 1592, s. 106. Możliwe też, że sformułowanie to zależne jest od tekstu jednego z komentarzy Wujka, zob. niżej. 
były miasto Boga zakazał, $[\mathrm{C}]$ jakimi się wierni katolicy brzydzą, od nich uciekają i niezliczona liczba męczenników stąd wyszła, że się bałwanom nie chcieli pokłonić. Obrazy święte nie są u nas za bogi ani im chwały boskiej nie dajemy, i owszem, mówimy z mędrcem [Prz 13,10]: „Niesczęśliwa między umarłymi jest nadzieja tych, którzy bogami nazwali dzieła rąk ludzkich, złoto i srebro".

[D] Zakazał tedy Pan Bóg inszemu bogu mimo się chwały bądź wnętrznej, bądź powierzchnej oddawać, co się do obrazów ściągać nie może, bo obraz Boży nie jest inszy bóg ani cześć obraza jest cześć boga inszego. [E] Ktemu byłby Pan Bóg sobie przeciwny, kiedyby zakazował obrazow: bo je robić i stawiać rozkazał, co mamy z Pisma Świętego w księgach wtórych Mojżesza. Ucząc, jako miano robić skrzynię Testamentu Starego [Wj 25,18], kazał cherubiny dwa złote uczynić. Także rozkazał Mojżeszowi urobić węża [Lb 21,8]. W Księgach Królewskich najdziesz, jako Salomon jeszcze będąc w łasce Bożej i wolą jego pełniąc, wystawiał w pojśrzodku kościoła dwa cherubiny [1 Krl 6,24.]. Tamże wołów dwunastu, na których morze lite stało, lwów też dwanaście u majestatu królewskiego [1 Krl 7,25]. Wiara, podobieństwo cherubinów i na skrzyni, i w kościele obrazami były prawdziwymi, bałwanami nie były, jako i obrazy wołów i lwów podobieństwa były z wolej Bożej. Toć tedy Pan Bóg obrazów nie zabronił i nie zakazał. [F] I owszem, tamże Pan Bóg rzemiesła malarskiego i snyczerskiego nauczył Bezelela i dał mu towarzysza Goliaba [Wj 31,2], a kiedyby obrazy miały być bałwanami, jako mówią nowowiernicy, toćby Pan Bóg nauczył robić bałwanów i byłby złego przyczyną, co stać nie może. Ale znać, że są Bogu przyjemne obrazy, bo dla nich dał rzemieślniki w Pismie Świętym zalecane.

[G] Na ostatek sam się Pan Bóg, oczywiście, widomie postać na się pewną biorąc, często pokazował Adamowi, Abrahamowi, Jakubowi, Mojżeszowi, za czym nosił na sobie obraz, skądby go Luter i Kalwin bałwochwalcą nazwali, bo używał obrazów, my zasię stądże dochodzimy, iż obrazy są dobre i Panu Bogu przyjemne, $[\mathrm{H}]$ zwłaszcza że sam Pan Bóg pierwszy na świecie obraz uczynił, bo człowieka na podobieństwo sobie stworzył, co mamy w piśmie Świętym wyraźnie. Bałwanów tedy Pan Bóg, nie obrazów, które sam postanowil, zakazał $[\ldots]^{36}$.

Celem syntetycznego i spójnego wywodu Biesiekierskiego jest odparcie zarzutu, jakoby katolicy mieli grzeszyć bałwochwalstwem [A]. Dlatego wyjaśnia różnicę między obrazem a bałwanem oraz defi-

36 A. Biesiekierski, Krótka nauka o czci i poszanowaniu obrazów świętych [...], Kraków: Maciej Jędrzejowczyk, 1624, k. 4v.-5v. 
niuje, na czym polega grzech bałwochwalstwa (na oddawaniu czci bałwanom, [B]). Katolicy nie popełniają bałwochwalstwa, ponieważ nie sporządzają bałwanów, a obrazom nie oddają czci Boskiej [C]. W dalszej części Biesiekierski wyjaśnia, że cześć oddawana obrazowi kieruje się do jego pierwowzoru [D], a sam Bóg nakazywał w Starym Testamencie sporządzać przedstawienia [E] i dlatego też nauczył ludzi rzemiosła $[\mathrm{F}]$. W ostatnim akapicie przekształca wątki Boskich epifanii oraz stworzenia człowieka na obraz w drobne arcydzieła retorycznej argumentacji. Gdyby obrazy były zupełnie zabronione, to Bóg byłby pierwszym bałwochwalcą, ponieważ przyjmował na siebie obrazy, ukazując się ludziom [G], oraz stworzył człowieka na Swój obraz $[\mathrm{H}]$.

Struktura wywodu Augustyna Biesiekierskiego jest zbliżona do haseł „bałwan” i „obraz” z Rejestru... oraz komentarzy, do których odsyła. Już w części [A] znajduje się sformułowanie bliźniaczo podobne do zdania $\mathrm{z}$ wykładu do Mdr 14,1 (nazwanego „bałwanów początek i przyczyna”): „żadnego stworzenia za Boga nie chwalimy, dlatego też nie masz w Kościele Bożym bałwanów, jako nas niewstydliwie heretycy potwarzają".

Piotr Krasny dostrzegł analogię do Bellarminowego simulacrum w słowie „podobieństwo” ze zdania: „Pan Bóg podobieństwa albo bałwanów, które były miasto Boga, zakazał". Tymczasem bezpośrednim odpowiednikiem simulacrum jest raczej „bałwan”. We fragmencie [B] Biesiekierski następująco definiuje człony Bellarminowej opozycji: bałwany „są znakami fałszywemi rzeczy fałszywych”, obrazy z kolei - „znakami prawdziwemi rzeczy prawdziwych”. W platońsko-arystotelesowskim paradygmacie fałsz był jednym z imion niebytu. Definicje Biesiekierskiego ze zdublowanymi pojęciami prawdziwości i fałszywości można by więc rozumieć następująco - obraz jest wiernym przedstawieniem (tzn. prawdziwym znakiem) rzeczy realnie istniejącej (tzn. prawdziwej), z kolei bałwan - zwodzącym na manowce przedstawieniem (a raczej nieudolną próbą przedstawienia, tzn. fałszywym znakiem) rzeczy zmyślonej, tworu wyobraźni, czegoś pozbawionego realnego istnienia (tzn. rzeczy fałszywej). Tak enigmatyczne zdefiniowanie typów przedstawień ze względu na 
ich relację do pierwowzoru, choć zgodne z myślą włoskiego jezuity, daleko odbiega od precyzji jego sformułowań. Definicja podąża jednak za uproszczoną adaptacją opozycji z komentarza do Wj 20,4 (w Rejestrze... określonego jako „bałwany czym różne od obrazów”): „Obraz jest prawdziwe jakiej rzeczy prawdziwej podobieństwo [...], bałwan lepak jest fałszywe podobieństwo, to jest, znaczy to, czego prawdziwie nie masz [...], a tak [rzeźby pogan] ani prawdziwie znaczyły, ale były fałszywe znaki” (zob. tabela 1, 1). W tym sformułowaniu znajdują się zarówno: pojęcie znaku (odpowiednik łacińskiego repraesentatio, inny niż np. u Birkowskiego ${ }^{37}$ ), jak i kategorie fałszywości i prawdziwości, ta ostatnia w dodatku zdublowana jak w Krótkiej nauce...

Analizy treści pierwszego przykazania, jaką proponuje Biesiekierski w [B], nie zawierają explicite komentarze, do których odsyła Rejestr... Rozważana była jednak w komentarzu do Ps 113,16. Werset ten często przywoływano $\mathrm{w}$ atakach na przypisywane katolikom bałwochwalstwo ${ }^{38}$, mógł więc wzbudzić zainteresowanie Biesiekierskiego przy pracy nad Krótką naukq̨... Komentarz brzmi: „Bo co indziej napisano: «Nie czyń sobie ryciny ani żadnego podobieństwa, nie kłaniaj się mu ani chwały dawaj», to tak na drugim miejscu wyłożono: «Nie czyń (na to), abyś się im kłaniał»". Warunkiem bałwochwalstwa jest więc dopiero „chwalstwo”, oddawanie nieuprawnionej czci przedstawieniu. Autor wykładu - tak jak i Biesiekierski posłużył się parafrazą $\mathrm{w}$ drugiej osobie liczby pojedynczej, a na marginesie znajduje się odsyłacz do Kpł 26,1. Dalsze słowa części [B], „widzimy, iż Pan Bóg podobieństwa abo bałwanów, które były miasto Boga, zakazał", uznać można za dalekie echo fragmentu komentarza do Wj 20,4 (zob. tabela 1, 9): „Grzeszy ten przeciw przykaza-

37 Zob. przypis 32.

38 Zob. K. Meller, „Pan Krystus po świecie rozesłał nie malarze, ale nauczyciele...". Głos polskich pisarzy protestanckich XVI wieku o katolickiej ikonodulii, w: Ikonoklazm i ikonofilia. Między historią a wspótczesnością, red. A. Stankowska, M. Telicki, Poznań 2016, s. 21. 
niu Bożemu, kto rycie abo podobieństwa jakie czyni, aby je za bogi chwalił”. Z kolei w części [C] odrzucenie zarzutów, jakoby katolicy mieli dopuszczać się bałwochwalstwa, oparte na stwierdzeniu, że nie mają swoich obrazów za bogów, znajduje się w wykładach do Wj 20,4 i Ba 6,3 (pod hasłem „obrazy nie są bałwanami”).

Rozróżnienie na chwałę „wnętrzną" i „zewnętrzną" obecne w [D] znajduje się zarówno w Disputationes..., jak i komentarzu do Wj 20,4 (zob. tabela 1, 4). Podobnie zastrzeżenie, że zakaz oddawania czci „do obrazów ściągać [się] nie może, bo obraz Boży nie jest inszy bóg ani cześć obraza jest cześć boga inszego". Analogiczne sformułowania zawierają komentarze do Flp 2,10 (w Rejestrze... określony „obrazom jako cześć wyrządzamy”) oraz do Ap 13,14 (w Rejestrze...: „Cześć obrazów ściąga się na tego, którego obrazy są"), odpowiednio: „Widząc obraz Pana Jezusów nie drewnu ani materyjej, nie farbam ani malowaniu, ale samemu Panu Jezusowi, którego on obraz znaczy i przed oczy stawia, się kłaniamy” i: „Cześć obrazu Pana Chrystusowego jest cześć Pana Chrystusowa, a nic nie ujmuje czci i chwale jego".

Materiał egzemplifikacyjny z części [E] cytowanego rozdziału Krótkiej nauki... może pochodzić zarówno z Disputationes..., jak i z miejsc w Biblii, do których odsyła Rejestr..., i znajdujących się przy danych fragmentach dalszych marginalnych odnośników. Warto podkreślić, że w pewnym sensie realizuje hasła z Rejestru...: „[obrazy] były w Starym Testamencie [...] i owszem, Bóg kazał obrazy czynić". Część $[\mathrm{F}]$ Biesiekierski mógł wywieść $\mathrm{z}$ obu omawianych źródeł (zob. tabela 1, 7).

Interesujące są argumenty zawarte w częściach [G] i [H]. Rozważania nad epifaniami Boga w Starym Testamencie oraz kwestia stworzenia człowieka na obraz Boży znajdują się w Non esse prohibitas imagines Dei, brak tam jednak tez, jakoby Bóg „przyjmował na siebie obraz" oraz że jeśli stworzył człowieka na swój obraz, a obrazy są absolutnie zakazane, to byłby pierwszym bałwochwalcą. $\mathrm{O}$ ile pod względem teologicznym argumenty te są słabe (choćby dlatego, że nie musi być dopuszczone człowiekowi to, co może czynić Bóg; jak sam napisał w dalszej części nauki Biesiekierski: „Wolno Mu, ni- 
komu nie podległ", k. 6v.), o tyle mogły mieć pewną moc perswazyjną, zwłaszcza dla odbiorców „podatnych - jak pisze Krasny - na retoryczną wyrazistość oracji”’39. Na niezależność tego fragmentu od omawianych źródeł wskazuje fakt, że - w odróżnieniu od innych cząstek - nie ma przy nim jakichkolwiek siglów biblijnych. Każdy teolog musiał wiedzieć, jak Bóg stworzył człowieka, zapewne pamiętał także, komu się ukazywał. Przedstawione w $[\mathrm{G}]$ i $[\mathrm{H}]$ oparte na tych fragmentach Biblii argumenty jawią się więc jako autorski wkład Biesiekierskiego w dysputę nad prawomocnością przedstawień. (Oczywiście nie można wykluczyć, że zaczerpnął je z innego źródła).

Omówiony wywód Augustyna Biesiekierskiego wykazuje wiele zbieżności z Rejestrem... z Biblii z 1599 roku i wykładami, do których odsyła. Rozdział Krótkiej nauki... realizuje praktycznie wszystkie wątki tematyczne z hasła „obraz”, z pominięciem punktów poświęconych cudom i pożytkom z obrazów, które autor omówił $\mathrm{w}$ kolejnych rozdziałach. Być może to hasło z biblijnego Rejestru... wyznaczyło ramy wywodu Biesiekierskiego? Poza tym wiele kategorii, również o bellarminowskiej proweniencji, autor Krótkiej nauki... mógł zaczerpnąć z komentarzy biblijnych, przede wszystkim - opozycję imago-idolum. Tezę o zapożyczeniu rozprawy w wykładach wspiera także obecność podobnych sformułowań w obu tekstach.

\section{Zakończenie}

Ech bellarminowskiego rozróżnienia na imago-idolum można doszukiwać się również w Czarownicy powołanej..., druku z 1639 roku, którego autorstwa dotychczas nie ustalono. W Pytaniu I. Co to superstitia abo zabobon? a co maleficium abo czary? między fragmentami

39 P. Krasny, Visibilia signa ad pietatem excitantes..., s. 189. 
o zabobonnych praktykach oraz wieszczbiarstwie znajduje się akapit poświęcony bałwochwalstwu:

Bałwochwalstwo tedy jest wszelka cześć, którą jakiemużkolwiek stworzeniu jako Bogu wyrządzamy. Jednak z tą przestrogą, abyś obrazów Chrystusa Pana i świętych jego nie nazywał bałwanami ani tych, którzy je czczą, bałwochwalcami. Bo obrazów nie zowiemy bałwanami jako poganie ani boga$\mathrm{mi}$, ale są wizerunkami i obrazami rzeczy prawdziwych, które nam wyrażają i kładą przed oczy. Jako ręka królewska na podpisie listu jego i pieczęć nie jest król, pomazaniec Boży, jednak iż króla i wolą jego znaczy, czciemy ją, całujemy ją z uczciwością wszelaką jako samego króla ${ }^{40}$.

Niemożliwe chyba byłoby wskazanie jednego źródła tych krótkich rozważań, których autor nie powołuje się na żadne pisma. Zasadniczo przypominają one myśli zawarte zarówno w komentarzach Wujka, jak i przedstawione przez Biesiekierskiego w rozdziale drugim Krótkiej nauki... albo przez Birkowskiego w kazaniu $O$ świętych obraziech jako mają być szanowane ${ }^{41}$. Trudno też w ogóle stwierdzić,

40 [Autor nieznany], Czarownica powołana abo Krótka nauka i przestroga $z$ strony czarownic [...], Poznań: Wojciech Regulus, 1639, s. 24. Za wskazanie tego fragmentu dziękuję Sabinie Raczyńskiej i Igorowi Barkowskiemu.

${ }_{41}$ To właśnie sformułowania $\mathrm{z}$ tego kazania najbardziej przypomina wywód autora Czarownicy...: „Ale obrazy świętych i Chrystusowe nie mogą być nazwane bałwanami, albowiem są obrazami rzeczy prawdziwych, postanowione na reprezentacją tego, co w nich jest prawdziwego jako ani obraz królewski ma być nazwany bałwanem, albowiem reprezentuje to, co jest”, F. Birkowski, O świętych obrazach..., s. 72.

Warto zwrócić uwagę na argument oparty na czci należnej królewskiej pieczęci, który anonimowy autor rozwija w kolejnym akapicie: „karaniu podległy, kto by jaki kontempt pokazał i on znieważył. A ten grzech bardzo wielki bałwochwalstwa, bo cześć samemu Bogu winną wyrządza stworzeniu i nieprzyjacielowi Bożemu. Jako gdyby kto znał innego króla oprócz własnego i jemu cześć królewską wyrządzał, popadałby crimen laesae Maiestatis”, [Autor nieznany], Czarownica..., s. 24. W podobny sposób w kazaniu O obraziech wyraża się Wujek, „jako gdyby kto listy królewskie zdrapał i podeptał, chociażby po królu nie deptał: wszakże jednak iż ta zelżywość ściąga się na króla, który na nim opisał mandat swój, winien się stawa naruszenia majestatu królewskiego i obrażenia”, J. Wujek, O obraziech, s. 233. Omawiana tutaj metafora jest także zbieżna z Mt 6,24 oraz 1 Kor 8,5. Być może tej linii argumentacji 
czy sformułowanie, że katolickie przedstawienia „są wizerunkami i obrazami rzeczy prawdziwych", odzwierciedla Bellarminowską definicję. Fraza ta - jeśli chciałoby się dostrzec w niej przykład dalekiej, pośredniej recepcji myśli Bellarmina - jawiłaby się jako wyrażona w terminologii Wujka (albo Birkowskiego), uwzględniającej przede wszystkim „prawdziwość” obrazu w sensie realnego istnienia jego pierwowzoru. Nawet jeśli niemożliwe jest rozstrzygnięcie postawionego problemu, nie powinno się na pewno pomijać Wujkowych komentarzy biblijnych - choć zakres ich oddziaływania na piśmiennictwo religijne XVII wieku pozostaje na razie nieznany - jako ważnego ogniwa w pośredniej recepcji pism Bellarmina, a szerzej - jako źródła inwencji i struktury tekstów argumentacyjnych oraz rozmaitych tez teologicznych w ogóle.

Tytuł Biblii w przekładzie Wujka - Biblia [...] zwykładem katolickim trudniejszych miejsc do obrony wiary świętej powszechnej przeciw kacerstwom tych czasów należących - zawiera prawie dokładne tłumaczenie podtytułu dzieła Bellarmina, który brzmi: Adversus huius temporis haereticos, czyli „przeciw kacerzom tych czasów”. Być może nie bez przyczyny to simile pojawia się obok „katolickiego wykładu miejsc trudniejszych"? Odpowiedź na pytanie, czy Disputationes... były jego źródłem podstawowym, wymaga analizy komentarzy z całości Pisma Świętego i porównania ich z tekstem monumentalnych Disputationes... (bądź wybranych jego traktatów), a także korpusem wcześniejszych tekstów Wujka, którymi mógł się wspierać, a w przypadku Nowego Testamentu - również z annotations z The New Testament of Iesus Christ Faithfully Translated into English. Myślę, że warto podjąć takie badania: w pierwszej kolejności nad źródłami Wujkowych „wykładów miejsc trudniejszych”, a w dalszej perspekty-

dała początek gdzieś w mglistej przeszłości chrystologiczna metaforyka Bazylego Wielkiego (Chrystus jako obraz Króla, tzn. Boga Ojca), z której korzystało wielu apologetów przedstawień, zob. św. Bazyli Wielki, O Duchu Świętym, przeł. i oprac. A. Brzóstowska, wstęp J. Naumowicz, Warszawa 1999, s. 146. 
wie - nad oddziaływaniem Wujkowych komentarzy na piśmiennictwo Rzeczypospolitej.

\section{Bibliografia}

\section{Źródła}

[Autor nieznany], Czarownica powołana abo Krótka nauka i przestroga z strony czarownic [...], Poznań: Wojciech Regulus, 1639.

Bazyli Wielki, św., O Duchu Świętym, przeł. i oprac. A. Brzóstowska, wstęp J. Naumowicz, Warszawa 1999.

Bellarmin R., Disputationes de controversiis Christianae Fidei, vol. 1, Ingolstadt: David Sartorius, 1586.

Biblia Sacra vulgatae editionis, Roma: Typographia Apostolica Vaticana, 1592.

Biblia, to jest Księgi Starego i Nowego Przymierza, przeł. J. Wujek, Kraków: Drukarnia Łazarzowa, 1599.

Biesiekierski A., Krótka nauka o czci i poszanowaniu obrazów świętych [...], Kraków: Maciej Jędrzejowczyk, 1624.

Birkowski F., O świętych obrazach, jako mają być szanowane, w: Głos krwie b. Józefata Kunczewica archiepiskopa połockiego także b. Jana Sarkandra męczennika morawskiego i obrazu bransbergskiego przytem o śs. obrazach, jako maja być szanowane kazania czworo, Kraków 1859, s. 71-85.

Grzegorz z Żarnowca, Kazanie o obraziech i bałwaniech, w: Pisarze polskiego odrodzenia o sztuce, oprac. W. Tomkiewicz, Wrocław 1955, s. 218-232.

Konfesja sandomierska, oprac. K. Długosz-Kurczabowa, Warszawa 1995.

The New Testament of Iesus Christ Faithfully Translated into English, Reims: John Fogny, 1582.

Nowy Testament, przeł. J. Wujek, Kraków: Andrzej Piotrkowczyk, 1593.

Wujek J., Iudicium abo Rozsądek niektórych katolików o konfesjej sędomierskiej roku 1570 wydanej [...], Kraków: Mikołaj Szarfenberg, 1570.

Wujek J., O obraziech, w: Pisarze polskiego odrodzenia o sztuce, oprac. W. Tomkiewicz, Wrocław 1955, s. 233-242.

\section{Opracowania}

Bieńkowska D., Jak Jakub Wujek Pismo święte na język polski przekładał, „Bobolanum" 9 (1998), z. 1, s. 27-52.

Drzymała K., Wplyw księdza Stanisława Grodzickiego T.J. na tłumaczenie Biblii ks. Jakuba Wujka T.J., „Polonia Sacra” 4 (1951), nr 1, s. 71-80. 
Encyklopedia katolicka, red. F. Gryglewicz, R. Łukaszyk, Z. Sułowski, t. 2, Lublin 1985.

Frick D.A., Anglo-Polonica. The Rheims New Testament of 1582 and the Making of the Polish Catholic Bible, „The Polish Review” 36 (1991), s. 47-67.

Frick D.A., Polish Sacred Philology in the Reformation and the Counter-Reformation, London 1989.

Krasny P., Visibilia signa ad pietatem excitantes. Teoria sztuki sakralnej w pismach pisarzy kościelnych epoki nowożytnej, Kraków 2010.

Meller K., „Pan Krystus po świecie rozestał nie malarze, ale nauczyciele...”. Głos polskich pisarzy protestanckich XVI wieku o katolickiej ikonodulii, w: Ikonoklazm i ikonofilia. Między historia a wspótczesnością, red. A. Stankowska, M. Telicki, Poznań 2016, s. 15-34.

Nicko-Stępień P., Źródła dla komentarza tekstowego Nowego Testamentu w tłumaczeniu Jakuba Wujka z roku 1593. Studium Dz 2, 14-36, „Odrodzenie i Reformacja w Polsce" 61 (2017), s. 235-257.

Pietkiewicz R., Biblia Polonorum. Historia Biblii w języku polskim, t. 1, Poznań 2016, s. $465-469$.

Pietkiewicz R., Pismo Święte w języku polskim w latach 1518-1638. Sytuacja wyznaniowa w Polsce a rozwój edytorstwa biblijnego, Wrocław 2002.

Pietkiewicz R., Polskie antytrynitarskie przekłady Biblii w dialogu Pierwszej Rzeczypospolitej ze wschodnia i zachodnia Europa, w: Antytrynitaryzm w Pierwszej Rzeczypospolitej $w$ kontekście europejskim, red. M. Choptiany, P. Wilczek, Warszawa 2017, s. 262-286.

Rubik T., „Zgromadzenie marnych” - „zbór marności”. Ingerencja cenzorów w Psatterz przekładu Jakuba Wujka, w: Figura heretyka w nowożytnych sporach konfesyjnych, red. A. Bielak, W. Kordyzon, Warszawa 2017, s. 213-232.

Smereka W., Wstęp, w: Nowy Testament w przekładzie ks. dr Jakuba Wujka T.J. z roku 1593, Kraków 1966, s. VII-XLVIII.

Sobczykowa J., Myśl o języku w komentarzu biblijnym ks. Jakuba Wujka, Katowice 2001.

Urbański P., Roberto Bellarmino (1542-1621) i wpływ jego myśli na rozwój kulturowych oraz religijnych idei w Rzeczypospolitej, w: Formowanie kultury katolickiej $w$ dobie potrydenckiej. Powszechność i narodowość katolicyzmu polskiego, red. J. Dąbkowska-Kujko, Warszawa 2016, s. 180-221. 